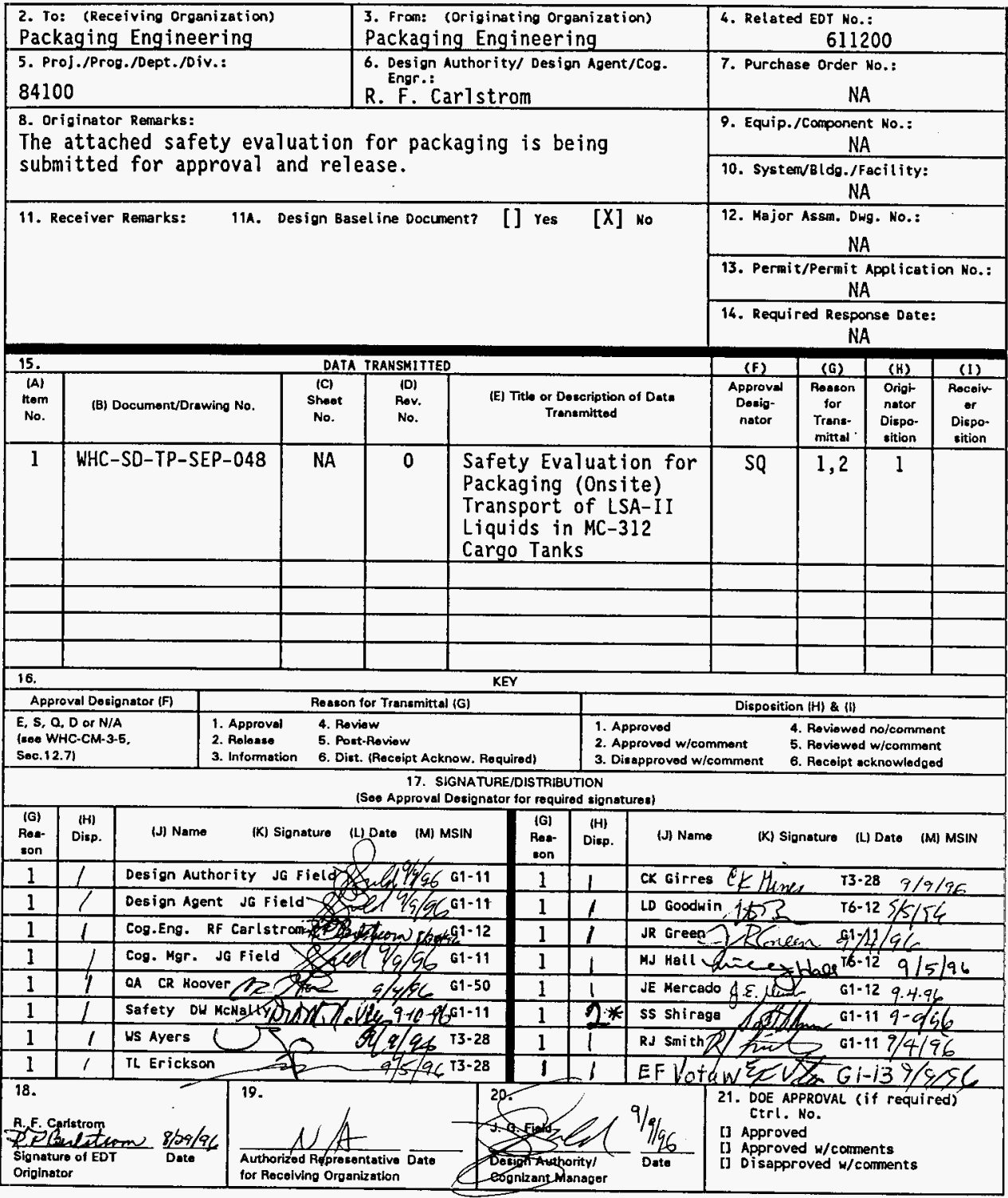

BD-7400-172-2 (05/96) GEF097

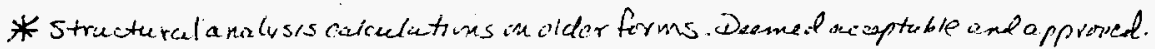




\section{Safety Evaluation for Packaging (Onsite) Transport of LSA-II Liquids in MC-312 Cargo Tanks}

R. F. Carlstrom

Westinghouse Hanford Company, Richland, WA 99352

U.S. Department of Energy Contract DE-ACO6-87RL10930

$\begin{array}{lll}\text { EDT/ECN: } & 618177 & \text { UC: } 513 \\ \text { Org Code: } 84100 & \text { Charge Code: YL056 } \\ \text { B\&R Code: } & \text { EW3130030 } & \text { Total Pages: } 98\end{array}$

Key Words: 222-S Cargo Tank, LETF Cargo Tanks, transfer

Abstract: This safety evaluation for packaging authorizes the onsite transfer of bulk LSA-II radioactive liquids in the 222-S Laboratory Cargo Tank and Liquid Effluent Treatment Facility Cargo Tanks (which are U.S. Department of Tranportation MC-312 specification cargo tanks) from their operating facilities to tank farm facilities.

TRADEMARK DISCLAIMER. Reference herein to any specific comereial product, process, or service by trade nerpe, trademark, marufacturer, or otherwise, does not necessarily constitute or imply its endorsement, recommendation, or favoring by the United states Government or any agency thereof or its contractors or subcontractors.

Printed in the United states of Nmerica. To obtain copies of this document, contact: WHC/BCS Document Control Services, P.0. Box 1970, Mailstop H6-08, Richland wA 99352, Phone (509) 372-2420; Fax (509) 376-4989.

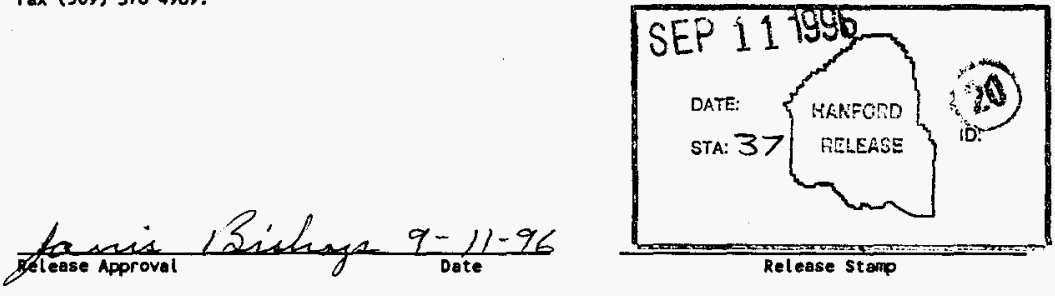


WHC-SD-TP-SEP-048

Rev. 0

LIST OF EFFECTIVE PAGES

\begin{tabular}{|c|c|c|}
\hline Page & Revision & Comment \\
\hline & 0 & EDT \\
\hline & 0 & SD Cover \\
\hline & 0 & ROR \\
\hline & 0 & LOEP \\
\hline iii-viii & 0 & TOC \\
\hline$A 1-1-A 1-2$ & 0 & \\
\hline$A 2-1-A 2-4$ & 0 & \\
\hline$A 3-1-A 3-2$ & 0 & \\
\hline$A 4-1$ - A4-2 & 0 & \\
\hline A5-1 - A5-2 & 0 & \\
\hline$A 6-1$ - A6-2 & 0 & \\
\hline$A 7-1-A 7-2$ & 0 & \\
\hline$A 8-1-A 8-2$ & 0 & \\
\hline A9-1 - A9-2 & 0 & \\
\hline$A 10-1-A 10-20$ & 0 & \\
\hline$B 1-1-B 1-2$ & 0 & \\
\hline$B 2-1-B 2-2$ & 0 & \\
\hline$B 3-1-B 3-2$ & 0 & \\
\hline B4-1-B4-8 & 0 & \\
\hline B5- 1 - B5-22 & 0 & \\
\hline$B 6-1-B 6-8$ & 0 & \\
\hline$B 7-1-B 7-6$ & 0 & \\
\hline B8-1 & 0 & \\
\hline
\end{tabular}


WHC-SD-TP-SEP-048 Rev. 0

CONTENTS

PART A: DESCRIPTION AND OPERATIONS

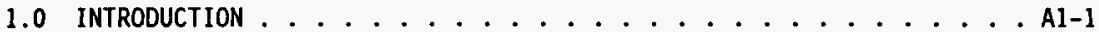

1.1 GENERAL INFORMATION .......................... . . . . . .

1.2 SYSTEM DESCRIPTION .................... Al-1

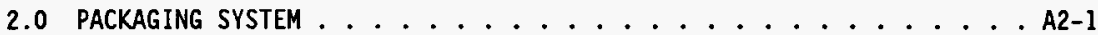

2.1 CONFIGURATION AND DIMENSIONS .....................

2.2 MATERIALS OF CONSTRUCTION ..................... A2-1

2.3 DESIGN AND FABRICATION METHODS . . . . . . . . . . . . A2-1

2.4 WEIGHTS AND CENTER OF GRAVITY . . . . . . . . . . . A2-2

2.5 CONTAINMENT BOUNDARY ............................

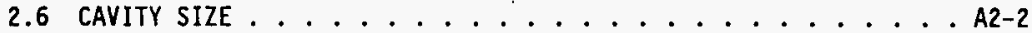

2.7 HEAT DISSIPATION . . . . . . . . . . . . . . A2-2

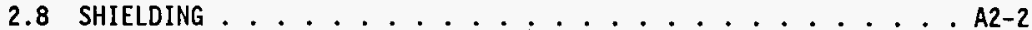

2.9 LIFTING DEVICES . . . . . . . . . . . . . . A2-3

2.10 TIEDOWN DEVICES ............................ . . .

3.0 PACKAGE CONTENTS . . . . . . . . . . . . . . A3-1

3.1 GENERAL DESCRIPTION . . . . . . . . . . . . A3-1

3.2 CONTENTS RESTRICTIONS . . . . . . . . . . . A3-1

3.2.1 Radioactive Materials ............. A3-1

3.2 .2 Hazardous Materials .............. A3-1

4.0 TRANSPORT SYSTEM . . . . . . . . . . . . . . . A4-1

4.1 TRANSPORTER . . . . . . . . . . . . . . . . . A4-1

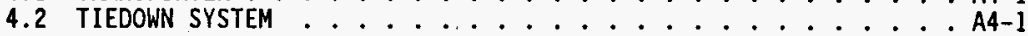

4.3 SPECIAL TRANSPORT REQUIREMENTS . . . . . . . . . . A4-1

4.3.1 Routing and Access Contro1 . . . . . . . . . A4-1

4.3.2 Radiological Limitations................. A4-1

4.3.3 Speed Limitations .................. A4-2

4.3.4 Environmental Conditions....................

4.3.5 Frequency of Use and Mileage Limitations........ A4-2

4.3.6 Emergency Response .................. A4-2

5.0 ACCEPTANCE OF PACKAGING FOR USE ............... . A5-1

5.1 ACCEPTANCE REQUIREMENTS ................ . . . . . . . .

5.1.1 Inspection and Testing. . . . . . . . . A5-1

5.1 .2 Documentation ....................... A5-1

5.2 PACKAGING FOR REUSE....................

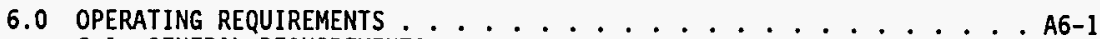

6.1 GENERAL REQUIREMENTS $\ldots \ldots \ldots \ldots$

6.2 LOADING/UNLOADING . . . . . . . . .

6.3 EMPTY PACKAGING . . . . . . . . . . . . . . . A6-2 


\section{CONTENTS (cont.)}

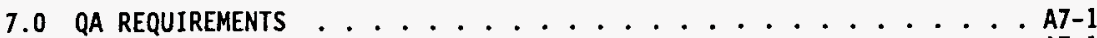

7.1 INTRODUCTION ........................ . .

7.2 SPECIFIC REQUIREMENTS . . . . . . . . . . . . . A7-1

7.2 .1 Design Control . . . . . . . . . . . A7-1

7.2 .2 Procurement Control . . . . . . . . . . A7-1

7.2.3 Control of In-Service Inspection and Testing ...... A7-1

7.2.4 Maintenance Checks and Controls .......... A7-2

7.2 .5 Records and Document Control . . . . . . . . A7-2

7.3 REVIEW AND UPDATE CYCLES .................... A7-2

8.0 MAINTENANCE . . . . . . . . . . . . . . . . A8-I

8.1 GENERAL REQUIREMENTS ................. A8-1

8.2 INSPECTION AND VERIFICATION SCHEDULES . . . . . . . . A8-1

8.3 RECORDS AND DOCUMENTATION .................... A8-2

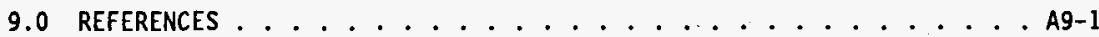

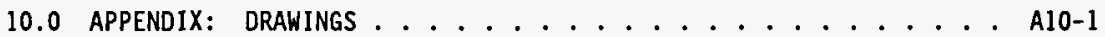

10.1 PIPING DIAGRAM--MC-312 CARGO TANKS ......... Al0-1

10.2 222-S LABORATORY MC-312 CARGO TANK DRAWINGS ...... A10-2

10.3 LETF MC-312 CARGO TANK DRAWINGS ........... A10-11

PART B: PACKAGE EVALUATION

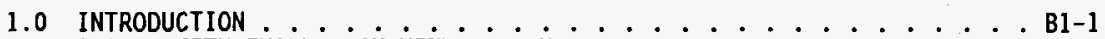

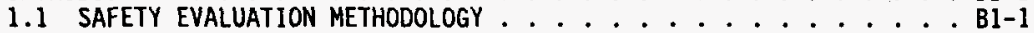

1.2 EVALUATION SUMMARY AND CONCLUSIONS ........... B1-1

1.3 REFERENCE . . . . . . . . . . . . . . . Bl-2

2.0 CONTENTS EVALUATION .......................... B2-1

2.1 CHARACTERIZATION ........................

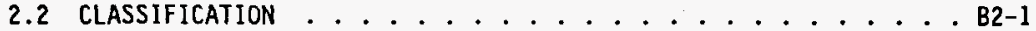

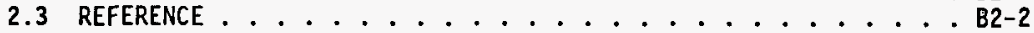

3.0 CONTAINMENT EVALUATION . . ............... B3-1

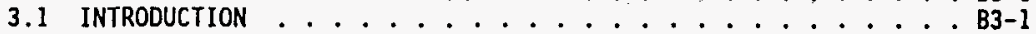

3.2 CONTAINMENT SOURCE SPECIFICATION .............. B3-1

3.3 NORMAL TRANSFER CONDITIONS .....................

3.3.1 Conditions To Be Evaluated . . . . . . . . . B3-1

3.3.2 Release Acceptance Criteria . . . . . . . . . . B3-1

3.3.3 Containment Evaluation ..................... B3-1

3.4 CONTAINMENT EVALUATION AND CONCLUSIONS ......... B3-2

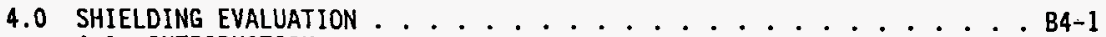

4.1 INTRODUCTION $\ldots \ldots \ldots \ldots$ B4-1 
WHC-SD-TP-SEP-048 Rev. 0

CONTENTS (cont.)

4.2 DiRECT RADIATION SOURCE SPECIFICATION ........... B4-1

4.2.1 Gamma Source.................. B4-1

4.2 .2 Beta Source ... . . . . . . . . . B4-1

4.2.3 Neutron Source . . . . . . . . . . B4-1

4.3 SUMMARY OF SHIELDING PROPERTIES OF MATERIALS . . . . . . B B-1

4.4 NORMAL TRANSFER CONDITIONS .............. B4-2

4.4.1 Conditions To Be Evaluated ............. B4-2

4.4.2 Acceptance Criteria .............. B4-2

4.4.3 Shielding Model ............. B4-3

4.4.4 Shielding Calculations ............ B4-3

4.5 SHIELDING EVALUATION AND CONCLUSIONS ......... B4-4

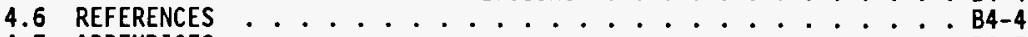

4.7 APPENDICES . . . . . . . . . B4-5

4.7.1 Listings of Selected iso-PC Input Files ..... B4-5

4.7.2 Justification for Exceeding $2-M$ and Driver

Location Dose Rates ............ . . 84-7

4.7.3 Checklist for Peer Review ................. B4-8

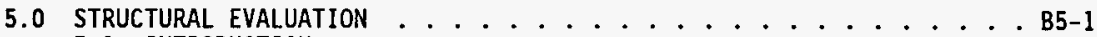

5.1 INTRODUCTION . . . . . . . . . . . . . B5-1

5.2 STRUCTURAL EVALUATION OF PACKAGE $\ldots \ldots \ldots \ldots$

5.2.1 Structural Design and Features .......... B5-1

5.2.2 Mechanical Properties of Materials ........ B5-1

5.2.3 Chemical and Galvanic Reactions ......... B5-2

5.2.4 Size of Package and Cavity . . . . . . . . B5-2

5.2.5 Weights and Center of Gravity ......... B5-2

5.2.6 Tamper-Indicating Feature ........... B5-2

5.2 .7 Positive Closure . . . . . . . . B5-2

5.2 .8 Lifting and Tiedown Devices .......... B5-3

5.3 NORMAL TRANSFER CONDITIONS ........................

5.3.1 Conditions To Be Evaluated . . . . . . . . B5-3

5.3.2 Acceptance Criteria ............ . . B5-3

5.3 .3 DOT Specification Evaluation . . . . . . . . B5-3

5.3 .4 Industrial Packaging 2 Evaluation ........ B5-7

5.3.5 Normal Transfer Conditions Evaluation ....... B5-9

5.4 STRUCTURAL EVALUATION AND CONCLUSIONS ......... B5-10

5.5 REFERENCES . . . . . . . . B B5-10

5.6 APPENDIX: STRUCTURAL ANALYSIS $\ldots \ldots$ B5-11

6.0 THERMAL EVALUATION ............................ B6-1

6.1 INTRODUCTION $\ldots \ldots \ldots$

6.2 THERMAL SOURCE SPECIFICATION

6.3 SUMMARY OF THERMAL PROPERTIES OF MATERIALS $\therefore: \cdots \cdots$ B6-1

6.4 THERMAL EVALUATION FOR NORMAL TRANSFER CONDITIONS $\ldots \ldots . .$. B6-1

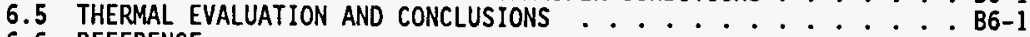

6.6 REFERENCE . . . . . . . . B6-2

6.7 APPENDIX: THERMAL EVALUATION ......................... 


\section{CONTENTS (cont.)}

7.0 PRESSURE AND GAS GENERATION ................... B7-1 7.1 GAS GENERATION ...................... 7.2 PACKAGE PRESSURE $\because \ldots$. . . . . . . . . .

7.3 APPENDIX: HYDROGEN GENERATION EVALUATION ........ B7-2

8.0 PACKAGE TIEDOWN SYSTEM EVALUATION .............. . . B8-1

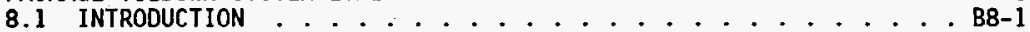

\section{LIST OF TABLES}

A4-1 External Container Contamination Limits . . . . . . . . . A4-2

B2-1 MC-312 Cargo Tank Radionuclide Activities . . . . . . . . B2-1

B4-1 222-S Cargo Tank Source Term . . . . . . . . . . . B4-2

B4-2 Dose Rates $(\mathrm{mrem} / \mathrm{h})$ Outside the 222-S Cargo Tank ........ B4-3

B4-3 Comparison of Maximum Dose Rates (mrem/h) With

Regulatory Limits ................. B4-4

B5-1 ASME Material Properties for Section VIII, Division 1, Materials ..................... . . . 


\section{LIST OF TERHS}

\begin{tabular}{|c|c|}
\hline 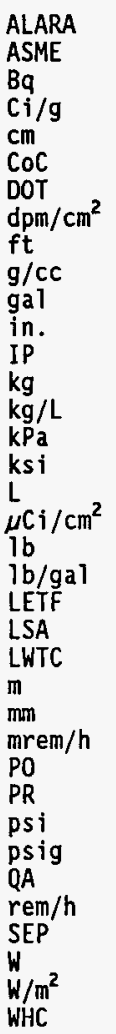 & $\begin{array}{l}\text { as low as reasonably achievable } \\
\text { American Society of Mechanical Engineers } \\
\text { becquerel } \\
\text { curies per gram } \\
\text { centimeter } \\
\text { certificate of compliance } \\
\text { U.S. Department of Transportation } \\
\text { disintegrations per minute per square centimeter } \\
\text { feet } \\
\text { grams per cubic centimeter } \\
\text { gallon } \\
\text { inch } \\
\text { Industrial Packaging } \\
\text { kilogram } \\
\text { kilograms per liter } \\
\text { kilopascal } \\
\text { l,o00-lb per square inch } \\
\text { liter } \\
\text { microcuries per square centimeter } \\
\text { pound } \\
\text { pound per gallon } \\
\text { Liquid Effluent Treatment Facility } \\
\text { low specific activity } \\
\text { liquid waste tank car } \\
\text { meter } \\
\text { millimeter } \\
\text { millirem per hour } \\
\text { purchase order } \\
\text { purchase requisition } \\
\text { pounds per square inch } \\
\text { pounds per square inch gage (pressure) } \\
\text { quality assurance } \\
\text { rem per hour } \\
\text { safety evaluation for packaging } \\
\text { watt } \\
\text { watts per square meter } \\
\text { Westinghouse Hanford Company }\end{array}$ \\
\hline
\end{tabular}




\section{WHC-SD-TP-SEP-048 Rev. 0}

This page intentionally left blank. 


\section{WHC-SD-TP-SEP-048 Rev. 0 \\ SAFETY EVALUATION FOR PACKAGING (ONSITE) TRANSPORT \\ OF LSA-II LIQUIDS IN MC-312 CARGO TANKS}

\section{PART A: DESCRIPTION AND OPERATIONS}

\subsection{INTRODUCTION}

\subsection{GENERAL INFORMATION}

Hanford Site facilities generate large volumes of liquid waste that is contaminated with low levels of radioactive materials. Transfers of low-level radioactive liquid wastes from operating facilities to tank farm facilities have typically been done through underground transfer lines or by the use of railroad liquid waste tank cars (LWTC). In specific cases, transfer of low-level liquid wastes by either of these methods is not operationally possible and/or is not cost effective. A safe and cost-effective means of packaging is required to transport low specific activity (LSA-II) liquid waste (up to $100 \mathrm{~A}_{2}$ s) from its generating facility to the tank farm facility. The 222-S Laboratory Cargo Tank (222-S Cargo Tank) and two Liquid Effluent Treatment Facility (LETF) Cargo Tanks have been identified as safe, costeffective packagings to transfer bulk low-level radioactive 1 iquid wastes; otherwise, new Industrial Packaging (IP) -2 approved bulk tank cars would need to be developed.

The purpose of this safety evaluation for packaging (SEP) is to authorize the onsite transfer of bulk LSA-II radioactive liquids in the 222-S Cargo Tank and LETF Cargo Tanks. Under the current U.S. Department of Transportation (DOT) regulations, the MC-312 Cargo Tanks are authorized for shipment in commerce of bulk LSA-I radioactive liquids only. The 222-S Cargo Tank (vehicle registration number H0-64-4275, serial number L1-10477) and the LETF Cargo Tanks (vehicle registration number H0-64-3858, serial number PI-12654, and vehicle registration number H0-64-3859, serial number P1-12655) are DOT MC-312 specification cargo tanks. This SEP provides the evaluation necessary to demonstrate that the 222-S Cargo Tank and the LETF Cargo Tanks meet the requirements of WHC-CM-2-14, Hazardous Material Packaging and Shipping; meet the MC-312 specification and DOT trailer rules; and provide similar safety functions as would be provided by IP-2 packagings. Operational, acceptance, maintenance, and quality assurance (QA) guidelines are established to ensure the method of transport for the 222-S Cargo Tank and LETF Cargo Tanks is performed safely and in accordance with WHC-CM-2-14.

\subsection{SYSTEM DESCRIPTION}

The 222-S Cargo Tank and LETF Cargo Tanks were fabricated to their original DOT specification (49 CFR 178.343 [1989]) and are authorized by this SEP to transport bulk LSA-II liquids. The three cargo tanks were manufactured by Polar Tank Trailer, Inc. Drawing information regarding the 222-s Cargo 
Tank and LETF Cargo Tanks transport systems with ancillary equipment and components is listed in Part $A$, Section 10.0, which includes the specific drawings, $\mathrm{H}-2-79957$ and $\mathrm{H}-9-203$, and a piping diagram.

The primary contents of the 222-S Cargo tank and LETF Cargo Tanks are LSA-II 1 iquids limited to $100 \mathrm{~A}_{2} \mathrm{~S}$ per shipment. The estimated maximum isotopic activities are provided in Part B, Table B2-1. The loaded 222-S Cargo Tank and LETF Cargo Tanks will be transported from the originating facility to the designated tank farm facility and unloaded of their liquid waste contents.

This SEP is a copy controlled supporting document to ensure that only up-to-date approved versions of this SEP are used for package transport. Any changes to this SEP will be performed by Westinghouse Hanford Company (WHC) Packaging Engineering and are incorporated and distributed to users through the copy control system. 
WHC-SD-TP-SEP-048 Rev. 0

\subsection{PACKAgING SYSTEM}

\subsection{CONFIGURATION AND DIMENSIONS}

The packaging system is an $18,925-\mathrm{L}$ (5,000-gal) DOT MC-312 specification cargo tank truck with a cleanbore straight-shape vessel. Each container is constructed of a $4.17-\mathrm{mm}$ (8-gauge) T316 stainless steel, two-piece barrel with one circumferential weld. The heads (ends) are fabricated from 4.76-mm (3/16-in.) T316L stainless steel and are butt welded to the barrel. The 11 stiffening rings are 304 stainless steel fully welded to the barrel and are 3.40-mm (10-gauge) $5.7-\mathrm{cm}(2 \mathrm{t}-\mathrm{in}$.$) channel. Each cargo tank is 147 \mathrm{~cm}$ (57t in.) in diameter, is $1,128 \mathrm{~cm}$ (444 in.) long, and is $133 \mathrm{~cm}$ (52k in.) above the ground on its transporter. The overall length of the cargo tank tractor and trailer is $1,615 \mathrm{~cm}$ ( $636 \mathrm{in.}$ ).

Each cargo tank has an American Society of Mechanical Engineers (ASME) tested $5.1-\mathrm{cm}(2.0-i n$.$) rupture disc with polyethylene drain tube located at$ the top center of the vessel. The $242-\mathrm{kPa}$ (35 psig) air inlet pressure package (consisting of a pressure gauge, ball valve, coupler, and ASMEapproved relief vaive) is mounted in the dam area. Each cargo tank also has a $7.6-\mathrm{cm}(3.0-i n$.$) stainless steel dip tube in the forward dam area. The dam is$ a part of the cargo tank flashing system and is built as a stainless steel construction spilibox with polyethylene drain hoses on each side, located just forward of the suspension system.

Each cargo tank is limited to a maximum volume of $15,140 \mathrm{~L}(4,000 \mathrm{gal})$ per shipment. The maximum operating system pressure is $242 \mathrm{kPa}$ (35 psi), and the design temperature is $52^{\circ} \mathrm{C}\left(125^{\circ} \mathrm{F}\right)$. The design specification states that the cargo tank was designed for 1 iquid weighing $1.92 \mathrm{~kg} / \mathrm{L}(16 \mathrm{lb} / \mathrm{ga} 1)$ or $36,287 \mathrm{~kg}(80,000 \mathrm{lb})$; however, the maximum payload authorized is $23,118 \mathrm{~kg}$ $(50,965 \mathrm{ib})$.

\subsection{MATERIALS OF CONSTRUCTION}

Barrel: 4.17-mm (8-gauge) SA-240, T316 stainless steel material

Heads: 4.76-mm (3/16-in.) SA-240, T316L stainless steel materia)

Rings: $3.40-\mathrm{mm}$ (10-gauge) SA-240, 304 stainless steel material, $5.7 \mathrm{~cm}$ (2⿺ in.) high

All other cargo tank support systems are constructed of various types of stainless steel.

\subsection{DESIGN AND FABRICATION METHODS}

The 222-S Cargo Tank and LETF Cargo Tanks were fabricated to the MC-312 DOT specification per 49 CFR 178.340 and 49 CFR 178.343 (1989). Each cargo tank is ASME certified and has a certificate of compliance (COC) that states the cargo tank was designed, constructed, and tested in accordance with DOT 
Motor Vehicle Cargo Tank Specifications for cargo tanks used for the transportation of classified liquids. See Part A, Section 5.0, for additional information on vessel design and fabrication.

\subsection{WEIGHTS AND CENTER OF GRAVITY}

The center of gravity of a completely full MC-312 Cargo Tank (18,925 L [5,000 gal]) is assumed to be at its geometric center. The cargo tank on its transporter is $133 \mathrm{~cm}(52.5 \mathrm{in.})$ above the ground. The coordinates of the center of gravity for the full MC-312 Cargo Tanks are:

$$
\begin{aligned}
& x--564 \mathrm{~cm}(222 \text { in. }) \\
& y-73.5 \mathrm{~cm}(28 \% \text { in.) } \\
& z--206.5 \mathrm{~cm} \text { (81\% in.). }
\end{aligned}
$$

The cargo tank is capable of carrying the maximum liquid specified, a maximum load of $23,118 \mathrm{~kg}(50,965 \mathrm{lb})$. The cargo tank trailer is capable of carrying the cargo tank assembly; ancillary equipment; and the maximum liquid volume specified, a maximum load of $34,885 \mathrm{~kg}(78,000 \mathrm{lb})$.

\subsection{CONTAINMENT BOUNDARY}

The containment boundary is provided by the stainless steel two-piece barrel and heads. Penetrations are provided on the top of the containment vessel for installation of the manhole cover, rupture disc, relief valve, pressure gauge, ball valve, coupler, and dip tubes. These penetrations with the installed components include bolted flanges with neoprene gaskets to seal the containment boundary. During transport of the loaded cargo tank, the valves are closed.

\subsection{CAVITY SIZE}

The cavity size of the 222-S Cargo Tank and the LETF Cargo Tanks is $146 \mathrm{~cm}$ (57\% in.) in diameter and $1,126 \mathrm{~cm}$ (443 in.) long.

\subsection{HEAT DISSIPATION}

The payload, which consists of LSA-II radioactive liquid, has a maximum decay heat less than 1 W. The 222-S Cargo Tank and LETF Cargo Tanks have no special cooling devices used to transfer or dissipate heat. Heat is passively dissipated.

\subsection{SHIELDING}

The stainless steel two-piece barrel provides negligible shielding capabilities. For transport of the loaded 222-S Cargo Tank and LETF Cargo Tanks, the radiological limitations of Part A, Section 4.3 .2 , shall be met. 


\subsection{LIFTING DEVICES}

Not applicable.

\subsection{TIEDOWN DEVICES}

The MC-312 Cargo Tanks are permanently secured to their transport trailers. The cargo tank is welded to the rear suspension system, which, in turn, is fastened to the trailer frame. The fifth-wheel assembly in front is fastened to the suspension system and trailer frame, using a heavy plate with an adjustable double-hubbed kingpin. No tiedown devices are required. 
WHC-SD-TP-SEP-048 Rev. 0

This page intentionally left blank. 
WHC-SD-TP-SEP-048 Rev. 0

\subsection{PACKAGE CONTENTS}

\subsection{GENERAL DESCRIPTION}

The authorized contents for the 222-S Cargo Tank and LETF Cargo Tanks are bulk liquid hazardous and radioactive materials.

\subsection{CONTENTS RESTRICTIONS}

\subsubsection{Radioactive Materials}

The radioactive source term is derived in Part B, Section 2.0, of this SEP. The liquid waste transported in the 222-S Cargo Tank and LETF Cargo Tanks shall meet the LSA-II definition for radioactive materials from 49 CFR 173.403 (1996) ( $<10^{-5} \mathrm{~A}_{2} / \mathrm{g}$ for liquids), shall be essentially uniformly distributed, shall not exceed $100 A_{2} s$, and shall be fissile excepted according to the requirements of 49 CFR 173.453 (1996).

\subsubsection{Hazardous Materials}

Any hazardous material transported in the 222-S Cargo Tank and LETF Cargo Tanks shall be authorized according to the MC-312 Cargo Tank DOT specification and as specifically authorized in 49 CFR 172.101 (1996), "Hazardous Materials Table," for transport of hazardous materials in bulk packagings. There are no flammable separable organic phases permitted. For unloading at tank farm facilities, the pH of the liquid waste is expected to be between 10.5 to 13 . Ions that may be present include chloride, nitrate, nitrite, carbonate, bicarbonate, phosphate, aluminum, sodium, fluorine, barium, cadmium, iron, lead, silver, arsenic, mercury, selenium, and chromium. 
WHC-SD-TP-SEP-048 Rev. 0

This page intentionally left blank. 
WHC-SD-TP-SEP-048 ReV. 0

\subsection{TRANSPORT SYSTEM}

\subsection{TRANSPORTER}

The transporter consists of the 34.9-metric ton (39-ton) capacity semitrailer and tractor with approximate dimensions of $16.4 \mathrm{~m}$ ( $53 \mathrm{ft}, 10 \mathrm{in}$.) long and $3 \mathrm{~m}$ (10 ft) wide.

\subsection{TIEDOWN SYSTEM}

The MC-312 Cargo Tanks are permanently secured to their transport trailers. No tiedown devices are required.

\subsection{SPECIAL TRANSPORT REQUIREMENTS}

\subsubsection{Routing and Access Control}

The 222-S Cargo Tank and LETF Cargo Tanks are authorized for onsite transfers only. Road closure shall be required for liquid waste transfers occurring south of the Wye Barricade and shall be conducted according to the Transportation Plan for "Non-DOT" Packages South of the Wye Barricade (WHC 1993). For liquid waste transfers north of the Wye Barricade, no road closures are required. The loaded cargo tank shall stop at all railroad crossings and proceed when determined safe to do so.

\subsubsection{Radiological Limitations}

The dose rate limitations must be less than $200 \mathrm{mrem} / \mathrm{h}$ at the surface of the cargo tank, less than $13 \mathrm{mrem} / \mathrm{h}$ at $2 \mathrm{~m}$ from the trailer, and less than $2 \mathrm{mrem} / \mathrm{h}$ at any space normally occupied by personnel. Transfer of the cargo tank above this limit is not authorized. From the shielding analysis in Part B, Section 4.0 , the projected dose rates meet these limits.

If dose rates exceed the occupied space limit, shielding (i.e., lead blankets or lead sheets) on the tractor-trailer may be added. Any added shielding shall not affect the cargo tank integrity and shall not affect transport system performance.

Nonessential personnel shall be restricted from receiving radiation exposure during the transfer. When the cargo tank is stationary, the controls specified in HSRCM-1, Hanford Site Radiological Control Manual, apply, including any posting for personnel exclusion areas.

The radiation work permit may require the driver to wear dosimetry.

The cargo tank should be transported as soon as possible after loading to reduce the possibility of increased dose rates due to settiing of particulate radioactive material. 
Permissible external contamination limits for the exterior of the 222-S Cargo Tank and LETF Cargo Tanks are as shown in Table A4-1.

Table A4-1. External Container Contamination Limits.

\begin{tabular}{|c|c|c|}
\hline \multirow{2}{*}{ Contaminant } & \multicolumn{2}{|c|}{ Maximum permissible limits } \\
\hline & $\mu \mathrm{Ci} / \mathrm{cm}^{2}$ & $\mathrm{dpm} / \mathrm{cm}^{2}$ \\
\hline $\begin{array}{l}\text { Beta-gamme emitting radionuclides; all radionuclides with } \\
\text { half-lives less than ten days; natura! uranium; natural } \\
\text { thorium; uranium-235; uranium-238; thorium-232; thorium- } \\
228 \text { and thorium-230 when contained in ores or physical } \\
\text { concentrates }\end{array}$ & $10^{-5}$ & 22 \\
\hline All other alpha emitting radionuclides & $10^{-6}$ & 2.2 \\
\hline
\end{tabular}

Source: 49 CFR 173.443, 1996, "Shippers*-General Requirements for Shipments and Packagings," Code of Federal Regulations, os amended.

\subsubsection{Speed Limitations}

The 222-S Cargo Tank and LETF Cargo Tanks shall observe posted speed limits for the Hanford Site.

\subsubsection{Environmental Conditions}

If extreme fog, ice, or adverse snow conditions exist, the 222-5 Cargo Tank and LETF Cargo Tanks shall not be transported.

\subsubsection{Frequency of Use and Mileage Limitations} limitations.

There are no restrictions for frequency of use, and there are no mileage

\subsubsection{Emergency Response}

The waste generating facility, Tank Farm Surveillance Operations, Radiation Protection, Packaging Engineering, and Hazardous Materials Operations shall be notified of all accidents involving radioactive material shipment that may result in vehicle damage, container damage, personnel injury, or contamination spread. 
WHC-SD-TP-SEP-048 ReV. 0

\subsection{ACCEPTANCE OF PACKAGING FOR USE}

\subsection{ACCEPTANCE REQUIREMENTS}

Details of the acceptance process are listed below.

\subsubsection{Inspection and Testing}

Final inspection and testing of the 222-S Cargo Tank and LETF Cargo Tanks were done by the vendor, Polar Tank Trailer, Inc., and witnessed by WHC nondestructive examination personnel and by ASME, the third-party inspector. The tests were documented in accordance with the procurement specification and are part of the $Q A$ data package. The cargo tanks have the required CoC from the vendor and are forwarded to the cargo tank custodian(s) vendor information file.

\subsubsection{Documentation} vendor:

The following documents are provided in the QA data package from the

- Manufacturer's data report for the vessel

- ASME design certification

- $\mathrm{CoC}$ from the vendor. The CoC certifies that the MC-312 Cargo Tanks were designed, constructed, and tested in accordance with DOT Motor Vehicle Cargo Tank Specifications for cargo tanks used for the transportation of classified liquids

- Vessel fabrication, assembly, and test documentation for the vessel. Documentation includes final as-built fabrication drawings, engineering change notices, fabrication travelers, inspection records, nonconformance reports, material test reports, nondestructive examination and leak test reports, pressure test reports, weld qualifications, welder qualifications, stress calculations, and performance-oriented evaluations

- Specifications for two-piece barrel construction, rings, frame, upper fifth wheel, flashing system, manhole, undercarriage (suspension, subframe, springs, axles, oil seals, brakes, bumper, air system), rims and tires, tire carrier, fenders, mudfiaps, lights and wiring, walkway, ladder, hose carriers, valving and piping, top unloading (4-in. nozzle with blind flange), outlet valving and drain, venting, and painting

- Vendor's data for equipment furnished by the Seller is provided in the final document package. This includes vendor's data sheets (with identifying part numbers), test reports, warranties, parts list, and maintenance requirements. This applies to valve; sluicing equipment, and gauging equipment for process control. 
WHC-SD-TP-SEP-048 Rev. 0

\subsection{PACKAGING FOR REUSE}

The 222-S Cargo Tank and LETF Cargo Tanks have a design life of 30 years. In order to use the cargo tanks for that length of time, the maintenance and operating plans must be followed. Part A, Section 8.0, contains the requirements for testing, inspection, and documentation. 
WHC-SD-TP-SEP-048 Rev. 0

\subsection{OPERATING REQUIREMENTS}

\subsection{GENERAL REQUIREMENTS}

1. The approved SEP shall be considered the controlling document for the shipment of the 222-S Cargo Tank and LETF Cargo Tanks.

2. All applicable instructions and procedures for onsite shipments of radioactive materials specified in WHC-CM-2-14 shall be followed.

3. Operational controls presented in the SEP shall take priority over similar requirements presented in other WHC manuals, except where other WHC requirements are more restrictive.

4. The 222-S Cargo Tank and LETF Cargo Tanks and their design shall not be altered or revised without documented approval in accordance with WHC-CM-6-1, Standard Engineering Practices, and WHC-CM-2-14.

5. Written operating procedures shall be followed when loading, transferring, and unloading payloads in the 222-s Cargo Tank and LETF Cargo Tanks. These procedures shall provide instructions to ensure that the container is being used in accordance with this SEP. These procedures shall be reviewed and approved by Packaging Engineering.

6. Unless otherwise noted in Part A, Section 8.2 , it shall be verified by custodians prior to usage that the 222-S Cargo Tank and LETF Cargo Tanks comply with their original specification per 49 CFR 178.340 and 49 CFR 178.343 (1989).

7. Uniess otherwise noted in Part A, Section 8.2, the inspections of the 222-S Cargo Tank and LETF Cargo Tanks shail be done according to 49 CFR 180.407 (1989), "Requirements for test and inspection of specification cargo tanks."

8. As documented in Part A, Section 8.0, the 222-S Cargo Tank and LETF Cargo Tanks will not be fully DOT compliant upon the expiration dates of two inspections, and certification under these conditions must be withdrawn by the custodian. The conditions necessitating withdrawal of the certification must be recorded and signed on the written certification for the cargo tank. To avoid violation of DOT requirements, the specification plate must be covered in a secure manner.

\subsection{LOADING/UNLOADING}

1. The cargo tanks shall not exceed $99 \%$ working capacity according to the requirements of 49 CFR $173.24 b(a)$

2. Cargo tank loading and unloading shall be scheduled to minimize outdoor storage. The cargo tank shall be filled and emptied under strict liquid-level control. 


\section{WHC-SD-TP-SEP-048 Rev. 0}

3. The loaded cargo tank stored outdoors shall be visually inspected for leaks and abnormal conditions at least once a day. .

4. The loaded cargo tank shall not be left unattended en route.

5. For bulk, unpackaged, LSA-II radioactive liquids and other liquid hazardous material, transport shall comply with the requirements of Part A, Section 4.3.

\subsection{EMPTY PACKAGING}

After emptying its contents at the tank farm facility, the cargo tank shall be assumed to contain a minimum volume that cannot be removed. Transport of the empty cargo tank shall be done according to the same requirements of a loaded cargo tank. 
WHC-SD-TP-SEP-048 Rev. 0

\section{T.O QA REQUIREMENTS}

\subsection{INTRODUCTION}

WHC-CM-4-2, Quality Assurance Manual, and WHC-IP-0705, Quality Assurance Program Plan for the Hazardous Materials Transportation and Packaging Program (WHC 1995), describe the WHC QA program for radioactive material shipping packages. In addition, WHC-CM-2-14 defines specific quality-affecting responsibilities.

\subsection{SPECIFIC REQUIREMENTS}

These specific requirements apply to activities that could affect the safety basis or quality of the MC-312 Cargo Tank/Trailer system and associated hardware. The overall MC-312 Cargo Tank/Trailer system is classified as "Safety Significant" per Section 9.0 of WHC-CM-4-46.

Each cognizant engineer involved with procurement, use, or maintenance of the MC-312 Cargo Tank/Trailer system, or components thereof, is responsible for ensuring that the assigned tasks are performed in accordance with controlling $\mathrm{pl}$ ans and procedures, which must, in turn, conform to the governing DOT and WHC QA program requirements.

\subsubsection{Design Control}

The cargo tank is designed to comply with the performance requirements specified in $M C-312$, with the cargo tank designed in compliance with the ASME (1992). Modifications shall comply with the MC-312 specification.

\subsubsection{Procurement Control}

Procurement documentation for MC-312 Cargo Tank/Trailer items is initiated by the 222-S Laboratory and LETF design authorities. The standard WHC purchase requisition (PR) contains both the technical and QA requirements. The PR information is converted to a purchase order (PO) by the WHC Purchasing organization. The cognizant Quality Assurance engineer reviews and approves all PRs per WHC-CM-4-2.

Changes to the PR, or subsequent $P 0$, are subject to the same review and approval requirements as the original PR. QA requirements are imposed by WHC specifications, engineering drawings, or other QA documents.

\subsubsection{Control of In-Service Inspection and Testing}

Inspection and testing of cargo tank equipment shall be conducted according to applicable DOT MC-312 specification standards at a minimum. 


\subsubsection{Maintenance Checks and Controls}

The maintenance procedures (Part $A$, Section 8.0 ) establish, as appropriate, criteria for maintenance inspections/tests to be conducted by the user to ensure the cargo tank/trailer system maintains containment and is free of excessive contamination. The maintenance procedures also establish qualification criteria for responsible personnel who document and evaluate inspection/test results.

\subsubsection{Records and Document Control}

Records that furnish documentary evidence of quality shall be specified, prepared, and maintained per WHC-CM-4-2, WHC-CM-2-14, and WHC-CM-3-5, Document Control and Records Management Manual. All documents used to perform and/or verify quality-related activities shall be controlled. Controlled documents include, but are not limited to drawings, specifications, POs, inspection and test plans and procedures, reports, verification data, nonconformance reports, corrective action reports, this SEP, and operational and maintenance procedures.

The design authority is responsible for ensuring accessibility to the latest issue of all design and maintenance records.

The SEP document shall be copy controlled. Records associated with this SEP shall be retained for the life of the package by the SEP agent.

\subsection{REVIEH AND UPDATE CYCLES}

This SEP is subject to periodic review and updates. A review shall be performed every five years to ensure that all SEP evaluations and other included information meet new or revised regulatory and/or company requirements. The initial review and update of the SEP shall be early in the year 2001 . 
WHC-SD-TP-SEP-048 Rev. 0

\subsection{MAINTENANCE}

\subsection{GENERAL REQUIREMENTS}

The waste generating facility shall provide the procedures for the required maintenance, inspections, and testing of the cargo tank.

\subsection{INSPECTION AND VERIFICATION SCHEDULES}

1. Maintain the DOT inspections, as follows.

- Prior to loading of the cargo tank, verify that the brakes and running gear preventive maintenance inspection is current.

- Verify the retest and inspection of the cargo tank are current according to the requirements of 49 CFR 180.407 (1989) with the two following exceptions.

- The inspection of tank exterior that is covered by the upper coupler (fifth wheel) assembly according to 49 CFR 180.407 (d)(2)(viji) (1989) is not required.

- The internal visual inspection according to 49 CFR 180.407 (e) (1989) is not required.

2. Quality Assurance inspection planning shall be established to ensure that inspection, prior to each use, verifies compliance with the following items.

- Cargo tank/trailer are properly assembled.

- Cargo tank is properly leak/pressure tested and satisfies the established criteria.

- All acceptance criteria are met for its use.

- All shipping papers are properly completed.

- Cargo tank/trailer is conspicuously and durably marked as required by the governing regulations.

- Measures are established to ensure that an individual, trained and certified as an onsite shipper, designated by the user of the cargo tank/trailer system, signs the shipping papers before authorization for shipping.

- Operational and maintenance procedures are properly completed. 


$$
\text { WHC-SD-TP-SEP-048 Rev. } 0
$$

3. Prior to departure (unloaded or loaded), the cargo tank shall be inspected for potentially hazardous conditions, as follows:

- Tank body leaning or listing, sagging, objects dragging below or extending to the side, any broken or missing safety appliances

- Corrosion or leaking around the upper coupler (fifth whee1) assembly

- Leaking of contents from cargo tank

- Any other condition considered likely to cause any significant problems before arrival at the cargo tank destination

- Tank, safety appurtenances, and fittings in proper condition for safe transportation (shipper must determine to the extent practicable).

A cargo tank that shows any of the defects mentioned above must not be offered for transportation until proper repairs have been made by the appropriate personnel.

\subsection{RECORDS AND DOCUNENTATION}

1. The design authority of each cargo tank, in accordance with the requirements of $W H C-C M-2-14$, shall obtain and retain the manufacturer's data report or certificate that the specification cargo tank was manufactured and tested in accordance with the applicable specification. The custodian shall retain the documents throughout ownership of the specification cargo tank and for one year thereafter.

2. The maintenance records shall be maintained for the length of time the specification cargo tank is owned plus one year.

3. The test and inspection reports of the specification cargo tank shall be maintained until the next test and inspection of the same type is successfully completed.

4. As relief is provided for two inspection requirements from 49 CFR 180.407 (1989), the specification cargo tank will not be fully DOT compliant upon the expiration dates of these inspections, and certification under these conditions must be withdrawn by the custodian. The conditions necessitating withdrawal of the certification must be recorded and signed on the written certificate for the cargo tank. To maintain compliance with DOT requirements, the specification plate must be covered in a secure manner. 
WHC-SD-TP-SEP-048 Rev. 0

\subsection{REFERENCES}

49 CFR 173, 1996, "Shippers--General Requirements for Shipments and Packagings," Code of Federal Regulations, as amended.

49 CFR 178.343, 1989, "Specification MC-312; Cargo Tank," Code of Federal Regulations.

49 CFR 178 Subpart J, 1989, "Specifications for Containers for Motor Vehicle Transportation," Code of Federal Regulations.

49 CFR 180 Subpart E, 1989, "Qualification and Maintenance of Cargo Tanks," Code of Federal Regulations.

180.407, "Requirements for test and inspection of specification cargo tanks."

ASME, 1992, Section VIII, Division 1, ASME Boiler and Pressure Vessel Code, American Society of Mechanical Engineers, New York, New York.

HSRCM-1, Hanford Site Radiological Control Manual, Pacific Northwest National Laboratory, Richland, Washington.

WHC-CM-2-14, Hazardous Material Packaging and Shipping, Westinghouse Hanford Company, Richland, Washington.

WHC-CM-3-5, Document Control and Records Management Manual, Westinghouse Hanford Company, Richland, Washington.

WHC-CM-4-2, Quality Assurance Manual, Westinghouse Hanford Company, Richland, Washington.

WHC-CM-4-46, Nonreactor Facility Safety Analysis Manual, Westinghouse Hanford Company, Richland, Washington.

WHC-CM-6-1, Standard Engineering Practices, Westinghouse Hanford Company, Richl and, Washington.

WHC, 1995a, Quality Assurance Program for the Hazardous Materials

Transportation and Packaging Program, WHC-IP-0705, Westinghouse Hanford Company, Richland, Washington.

WHC, 1995b, Thermal Analysis Methods for Safety Analysis Reports for Packaging, WHC-SD-TP-RPT-005, Rev. 1, Westinghouse Hanford Company, Richland, Washington.

WHC, 1993, Transportation Plan for "Non-DOT" Packages South of the WYE Barricade, DI-84300-002, Transportation and Packaging, Westinghouse Hanford Company, Richland, Washington.

WHC, 1994, Report on Equivalent Safety for Transportation and Packaging of Radioactive Materials, WHC-SD-TP-RPT-001, Rev. 0, Westinghouse Hanford Company, Richland, Washington. 
WHC-SD-TP-SEP-048 ReV. 0

WHC, 1992, Environmental Conditions for On-Site Hazardous Materials Packages, WHC-SD-TP-RPT-004, Rev. 0, West inghouse Hanford Company, Richland, Washington.

WHC, 1989, Purchase Order WJP-XVV-041859, Westinghouse Hanford Company, Richi and, Washington, December 29. 
WHC-SD-TP-SEP-048 Rev. 0

10.0 APPENDIX: DRAMINGS

10.1 PIPING DIAGRAM--MC-312 CARGO TANKS

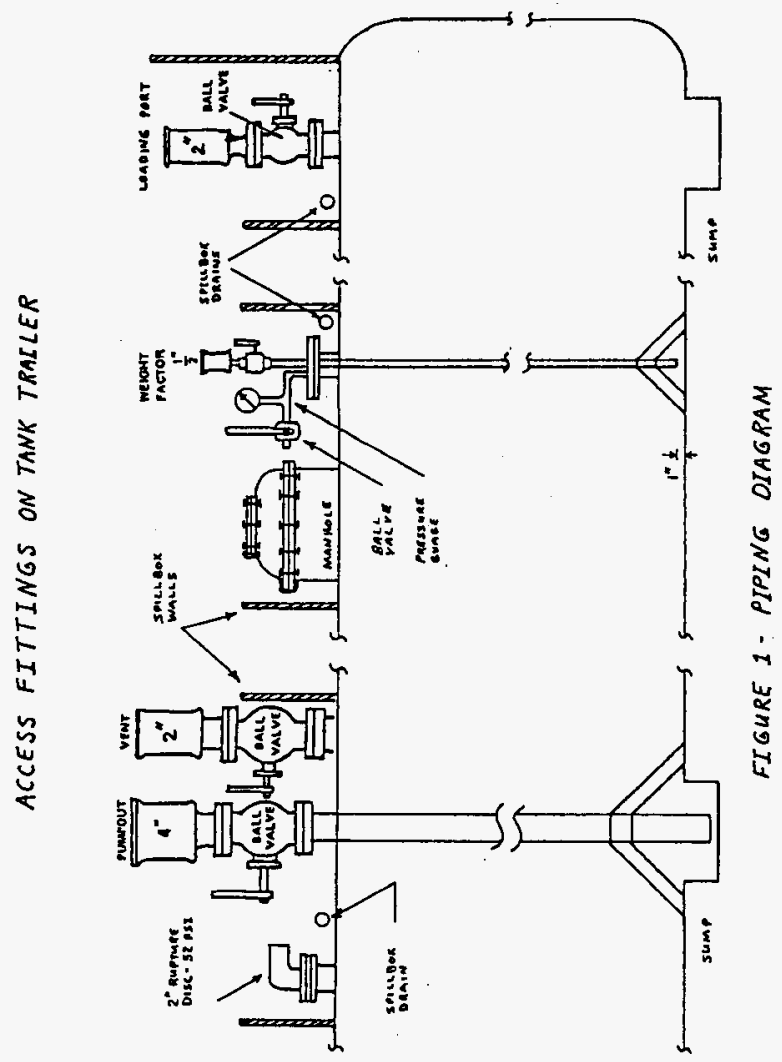


WHC-SD-TP-SEP-048 Rev. 0

10.2 222-S LABORATORY MC-312 CARGO TANK DRAWINGS (H-2-79957)

A10-2 


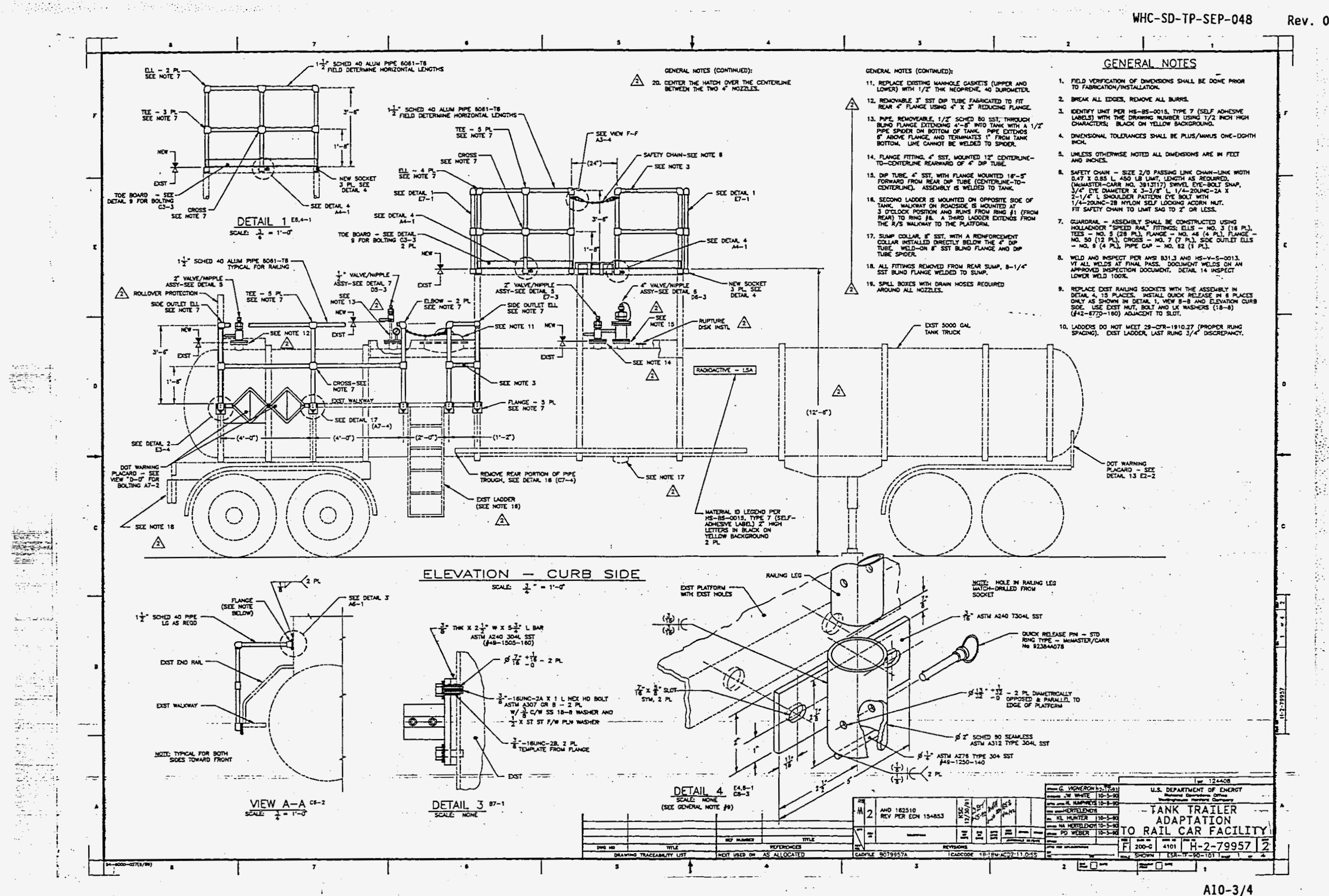




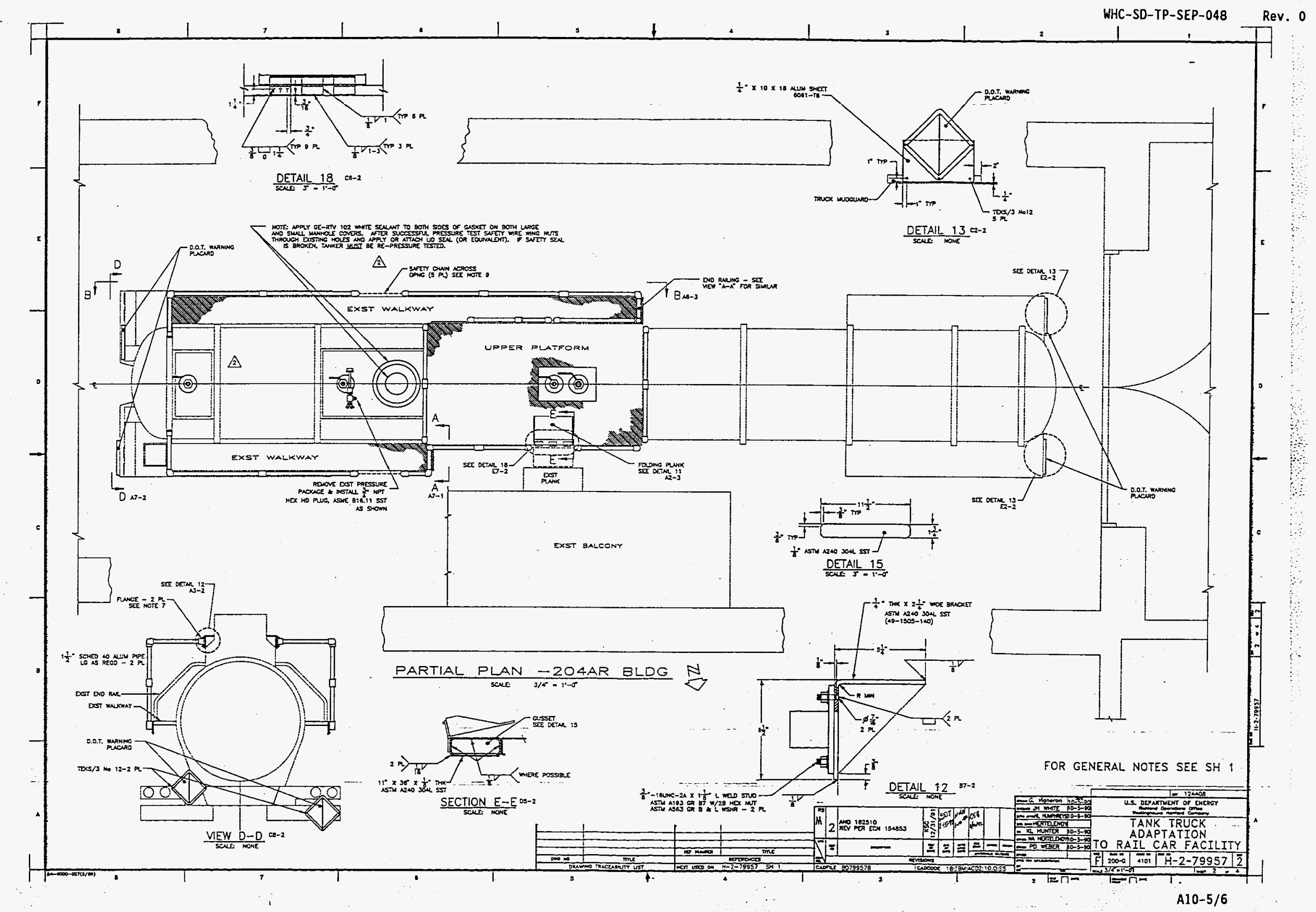




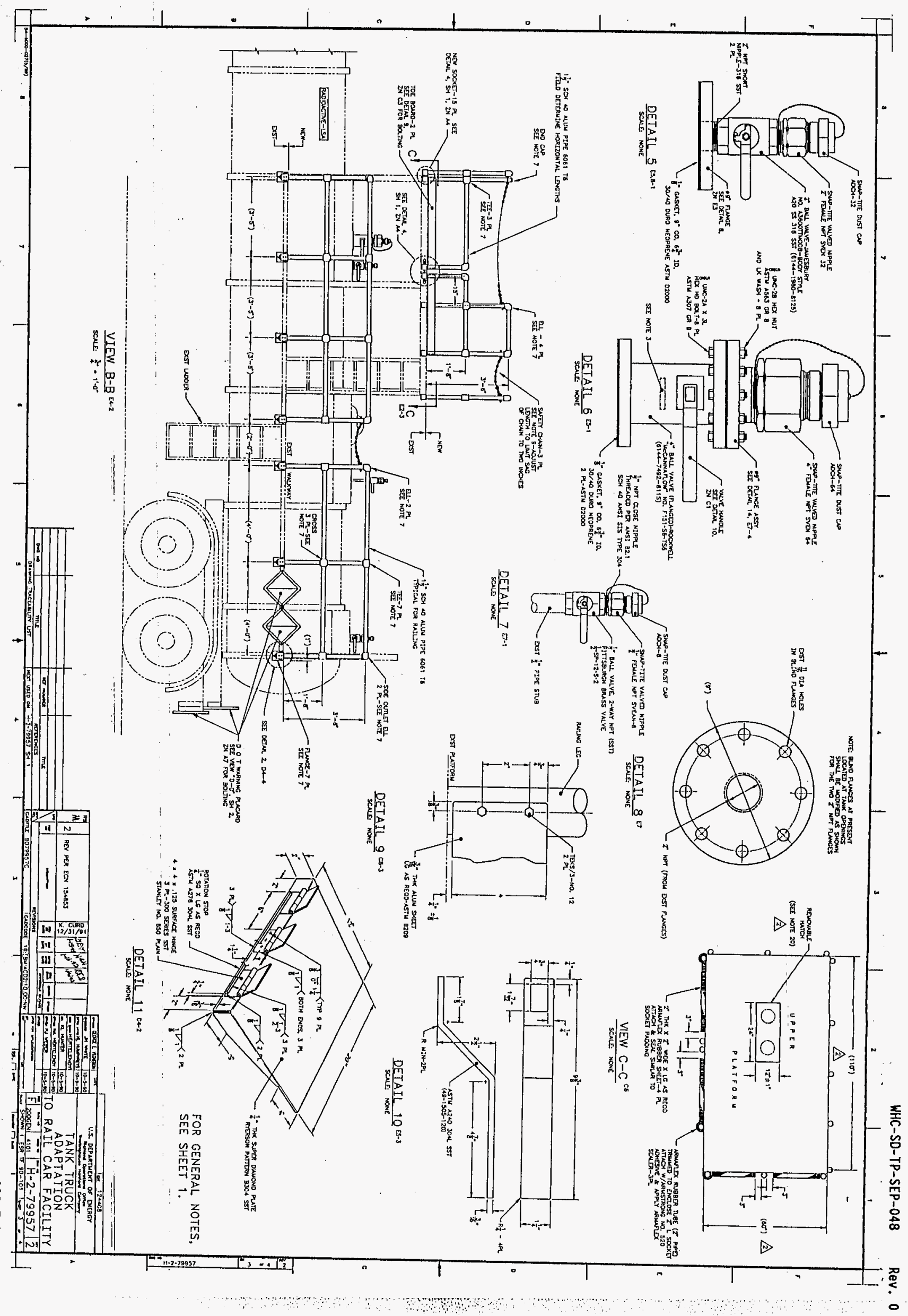




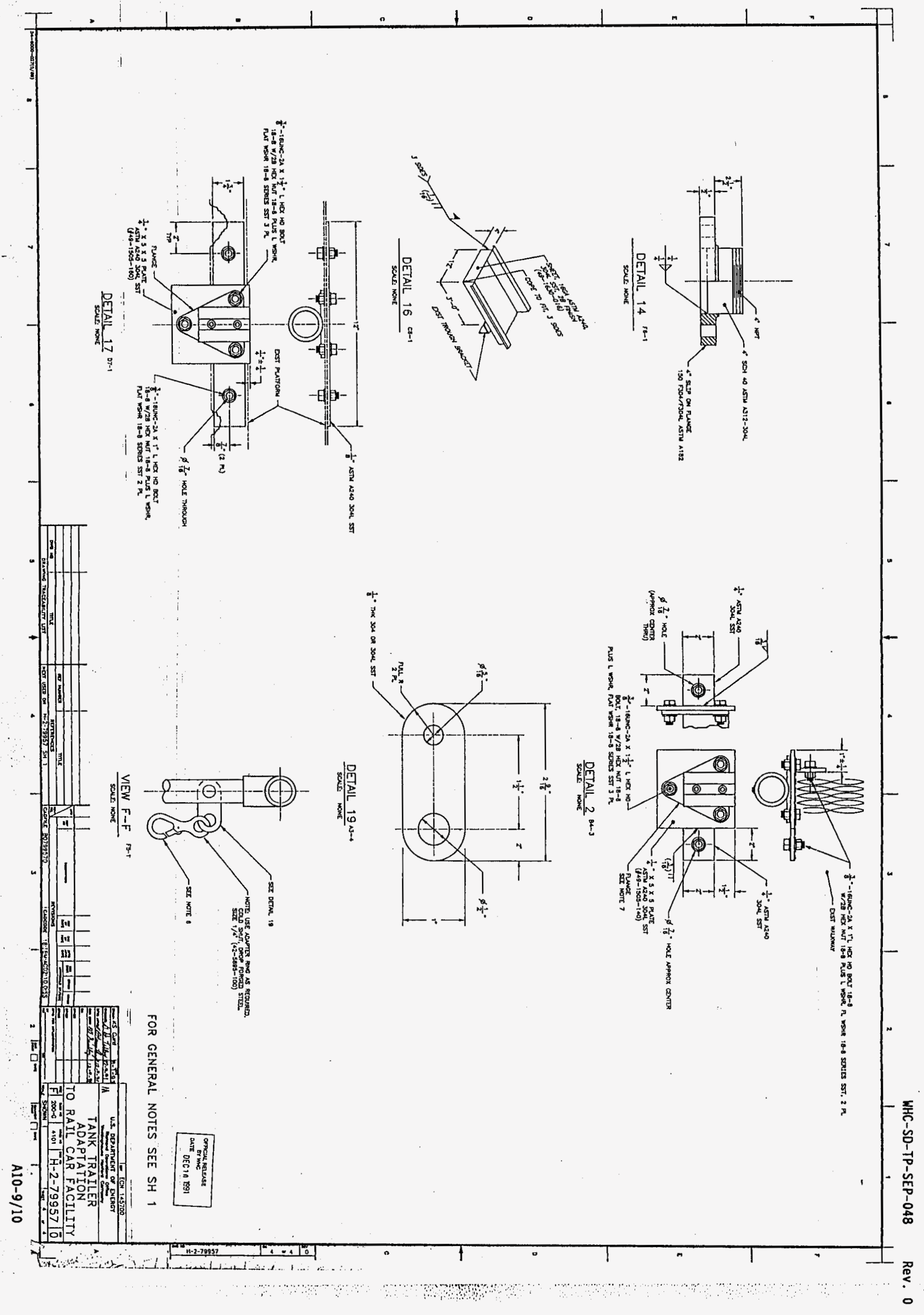


WHC-SD-TP-SEP-048 Rev. 0

10.3 LETF MC-312 CARGO TANK DRAWINGS (H-9-203) 


\section{WHC-SD-TP-SEP-048 Rev. 0}

This page intentionally left blank.

A10-12 


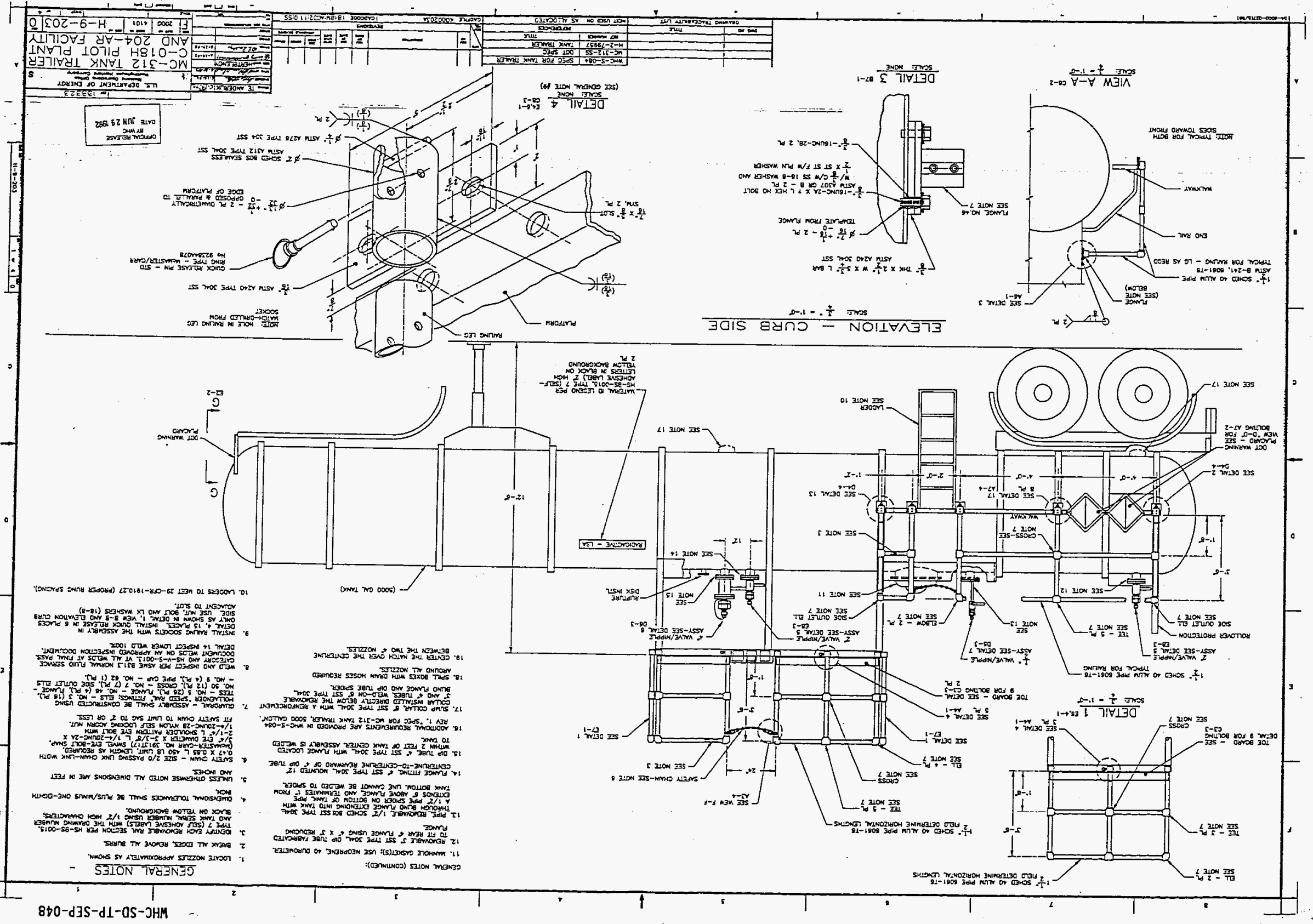




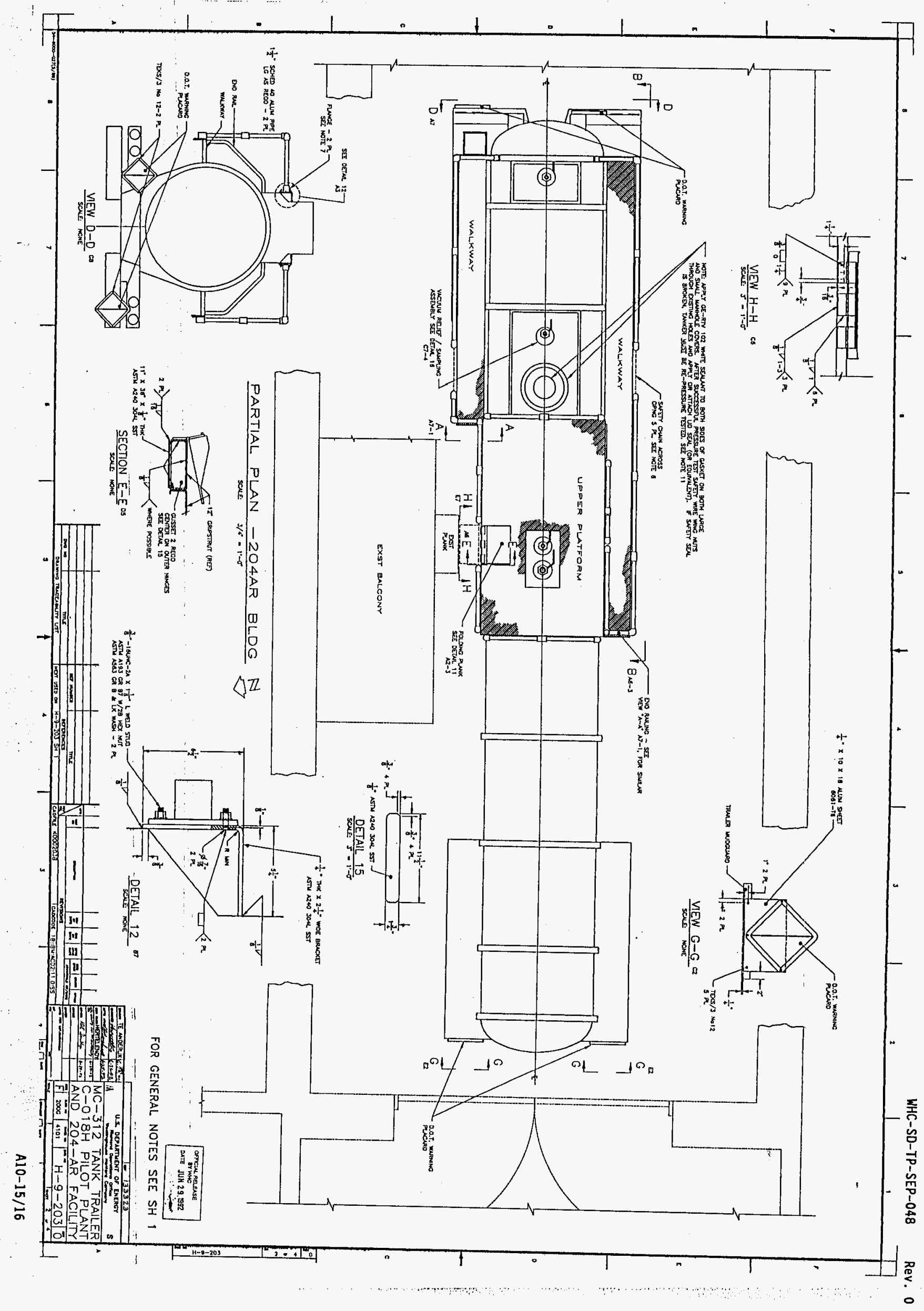




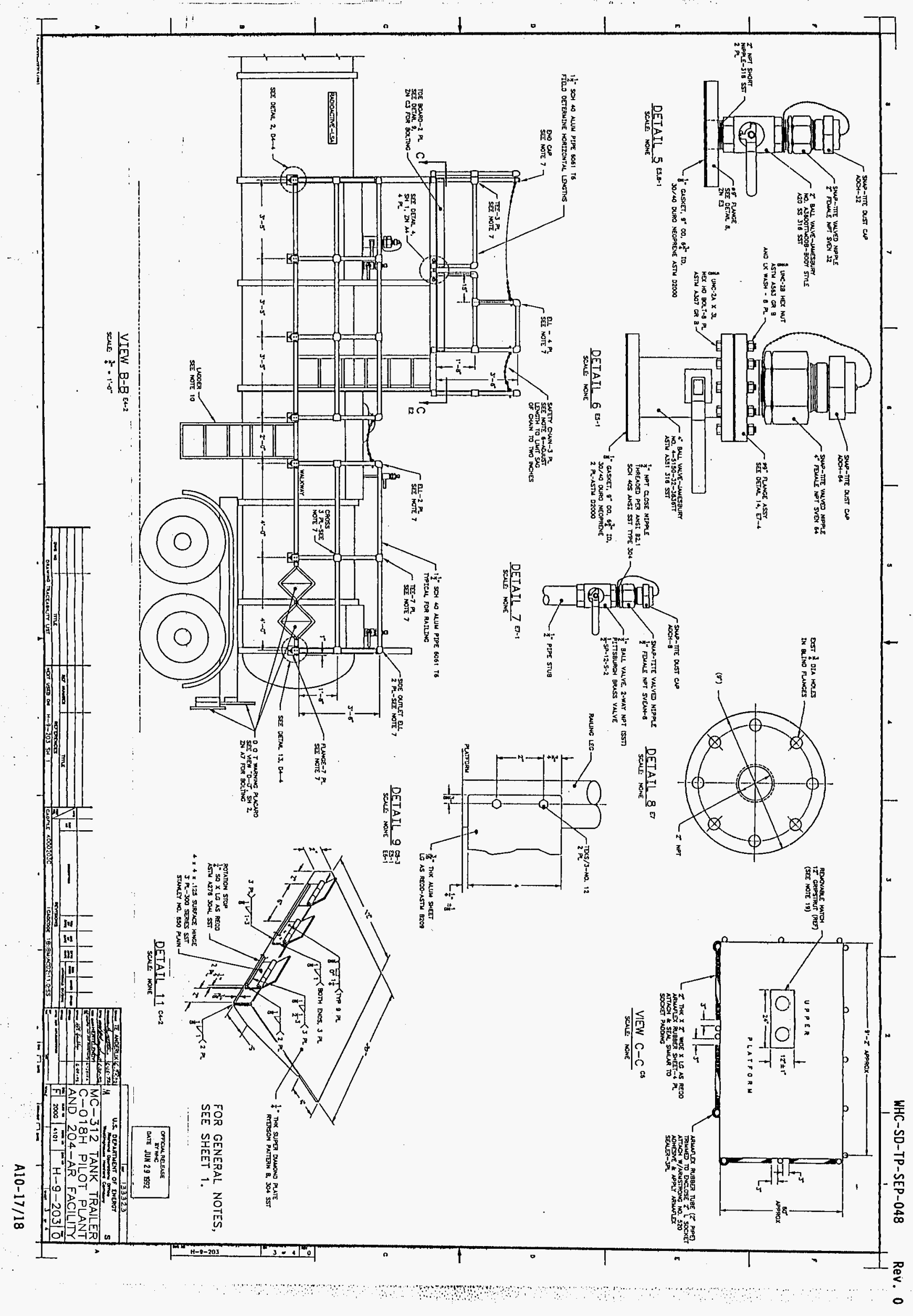




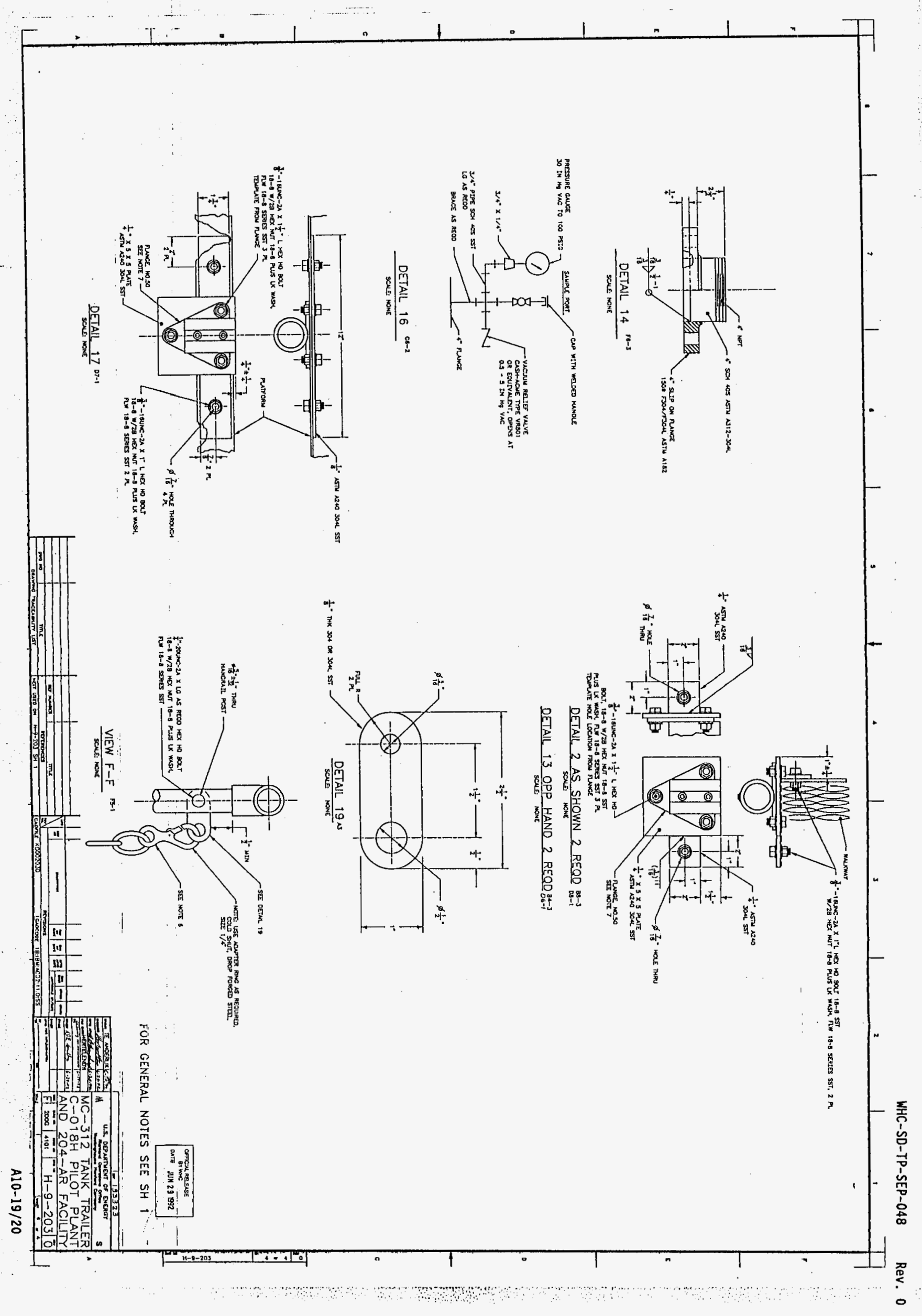


WHC-SD-TP-SEP-048 ReV. 0

\section{PART B: PACKAGE EVALUATION}

\subsection{INTRODUCTION}

\subsection{SAFETY EVALUATION METHODOLOGY}

The 222-S Laboratory Cargo Tank (222-S Cargo Tank) and Liquid Effluent Treatment Facility (LETF) Cargo Tanks were evaluated against the requirements of WHC-CM-2-14, Hazardous Materials Packaging and Shipping, for onsite transportation of bulk radioactive liquids that meet the low specific activity (LSA) - I I definition, are essentially uniformly distributed, do not exceed 100 $A_{2} s$, and are fissile excepted.

The analyses presented in this safety evaluation for packaging verify the cargo tanks meet the onsite transportation safety requirements based on the U.S. Department of Transportation (DOT) MC-312 specification, DOT trailer assembly, and comparative evaluation to Industrial Packaging (IP)-2 requirements.

\subsection{EVALUATION SUMMARY AND CONCLUSIONS}

The 222-S Cargo Tank and LETF Cargo Tanks are safe for the onsite transportation of bulk radioactive liquids that are LSA-II, are essentially uniformly distributed, do not exceed $100 \mathrm{~A}_{2} \mathrm{~s}$, and are fissile excepted.

The typical contents of the 222-S Cargo Tank and LETF Cargo Tanks are evaluated in Part B, Section 2.0 .

Containment was evaluated based on the MC-312 design and determined to be acceptable for the stated conditions of handling and onsite transfer. The containment evaluation is presented in Part B, Section 3.0.

The shielding analysis for the source term identified for the MC-312 Cargo Tanks indicates that the dose rate limit at the package surface would not be exceeded; however, the dose rate limits for the 2-m distance and driver location in the transport vehicle would be exceeded. To allow transport up to the maximum estimated dose rates, additional administrative controls are provided. Use of shielding material, if required, will be authorized to reduce the dose rate at the driver location. The shielding evaluation is presented in Part B, Section 4.0.

The structural evaluation demonstrates that the 222-S Cargo Tank and LETF Cargo Tanks meet their original MC-312 specification and relevant IP-2 requirements. The structural evaluation is presented in Part B, Section 5.0.

The thermal evaluation demonstrates that heat generation is not a concern due to the very low concentration of radionuclides, and package surface temperature limits will not be exceeded under the Hanford environmental conditions. The thermal evaluation is presented in Part B, Section 6.0. 
The gas generation analysis demonstrates that hydrogen generation rate is very low, and pressurization of the 222-S Cargo Tank and LETF Cargo Tanks is not of concern during transportation. The evaluations are presented in Part B, Section 7.0.

A package tiedown system evaluation was not conducted as the cargo tanks are permanently secured to their transporter in accordance with DOT requirements.

\subsection{REFERENCE}

WHC-CM-2-14, Hazardous Material Packaging and Shipping, Westinghouse Hanford Company, Richland, Washington. 


\subsection{CONTENTS EVALUATION}

\subsection{CHARACTERIZATION}

The payload of the 222-S Cargo Tank and LETF Cargo Tanks consists of bulk jiquids contaminated with radionuclides. The estimated contents are based on the highest activities of specific radionuclides that will be discharged into the waste liquid effluent. An example of previous radionuclide activities, associated daughter products, and fissile content are listed in Table B2-1.

Table B2-1. MC-312 Cargo Tank Radionuclide Activities."

\begin{tabular}{|c|c|c|c|c|c|c|}
\hline I sotope & $\begin{array}{l}\text { Activity } \\
\text { (Ci) }\end{array}$ & $\begin{array}{l}\text { Activity } \\
\text { (Bq) }\end{array}$ & $A_{2}(\mathrm{C} i)$ & $\begin{array}{l}\text { Quantity } \\
\text { (grams) }\end{array}$ & $\begin{array}{c}\text { Specific } \\
\text { activity } \\
\text { (Ci/g) }\end{array}$ & $\begin{array}{c}\text { Sum of } \\
\text { fraction } A_{2}\end{array}$ \\
\hline $\mathbf{3}_{\mathrm{H}}$ & 8.40 E-01 & $3.11 E+10$ & $1.08 \mathrm{E}+03$ & $8.66 E-05$ & $9.70 \mathrm{E}+03$ & $7.78 \mathrm{E}-04$ \\
\hline${ }^{14} \mathrm{C}$ & $6.50 \mathrm{E}-03$ & $2.40 \mathrm{E}+08$ & $5.61 \mathrm{E}+01$ & $1.44 E-03$ & $4.50 \mathrm{E}+00$ & $1.20 E-04$ \\
\hline${ }^{60} \mathrm{Co}$ & 4.35 E-01 & $1.61 \mathrm{E}+10$ & $1.08 \mathrm{E}+01$ & 3.95 E-04 & $1.10 E+03$ & $4.03 E-02$ \\
\hline${ }^{90} \mathrm{sr}$ & $2.63 E+00$ & $9.73 \mathrm{E}+10$ & $2.70 \mathrm{E}+00$ & $1.88 E-02$ & $1.40 E+02$ & 9.74 E-01 \\
\hline $90 \gamma$ & $2.63 E+00$ & $9.73 E+10$ & $5.41 \mathrm{E}+00$ & 4.87 E- 06 & $5.40 \mathrm{E}+05$ & $0.00 E+00$ \\
\hline${ }^{99}$ Tc & 5.50 E-02 & $2.03 E+09$ & $2.43 \mathrm{E}+01$ & $3.24 E+00$ & 1.70 E-02 & $2.26 \mathrm{E}-03$ \\
\hline $129_{I}$ & $4.80 \mathrm{E}-02$ & $1.78 E+09$ & Unlimited & $2.67 E+00$ & 1.80 E.04 & $0.00 \mathrm{E}+00$ \\
\hline${ }^{137} \mathrm{Cs}$ & $2.61 \mathrm{E}+00$ & $9.66 E+10$ & $1.35 \mathrm{E}+01$ & $3.00 \mathrm{E}-02$ & $8.70 \mathrm{E}+01$ & $1.93 \mathrm{E}-01$ \\
\hline $137 \mathrm{M}_{\mathrm{Ba}}$ & $2.47 \mathrm{E}+00$ & $9.14 E+10$ & $0.00 E+00$ & $0.00 E+00$ & $0.00 E+00$ & $0.00 \mathrm{E}+00$ \\
\hline $147 \mathrm{Pm}$ & $7.50 \mathrm{E}+00$ & $2.78 \mathrm{E}+11$ & $2.43 E+01$ & $9.30 E+02$ & $9.30 \mathrm{E}+02$ & 3.09 E-01 \\
\hline${ }^{154} \mathrm{Eu}$ & $5.54 \varepsilon-03$ & $2.05 E+08$ & $1.35 \mathrm{E}+01$ & $2.13 \mathrm{E}-05$ & $2.60 \mathrm{E}+02$ & $4.11 E-04$ \\
\hline${ }^{234} \mathrm{U}$ & $1.45 \mathrm{E}-02$ & $5.36 \mathrm{E}+08$ & 2.70 E-02 & $2.34 E+00$ & $6.20 \mathrm{E}-03$ & 5.37 E-01 \\
\hline${ }^{235} 5_{U^{\star *}}$ & 8.50 E-05 & $3.14 E+06$ & Unl imited & $3.86 E+01$ & $2.20 \mathrm{E}-06$ & $0.00 E+00$ \\
\hline $231 \mathrm{Th}$ & 8.50 E-05 & $3.14 E+06$ & $2.43 \mathrm{E}+01$ & $1.60 \mathrm{E}-10$ & $5.30 \mathrm{E}+05$ & $0.00 \mathrm{E}+00$ \\
\hline $238 \mathrm{U}$ & $1.40 \mathrm{E}-03$ & $5.18 \mathrm{E}+07$ & Unlimited & $4.12 E+03$ & $3.40 E-07$ & $0.00 E+00$ \\
\hline${ }^{238} 8_{\mathrm{Pu} * *}$ & $2.15 \mathrm{E}-02$ & $7.96 \mathrm{E}+08$ & $5.41 E-03$ & $1.26 \mathrm{E}-03$ & $1.70 \mathrm{E}+01$ & $3.97 \mathrm{E}+00$ \\
\hline $239^{\mathrm{Pu}}$ & 1.85 E-01 & $6.85 E+09$ & 5.41 E-03 & $2.98 \mathrm{E}+00$ & $6.20 \mathrm{E}-02$ & $3.42 \mathrm{E}+01$ \\
\hline $241_{\mathrm{Am}}$ & $1.45 \mathrm{E}-01$ & $5.36 \mathrm{E}+09$ & $5.41 \mathrm{E}-03$ & $4.26 \mathrm{E}-02$ & $3.40 \mathrm{E}+00$ & $2.68 \mathrm{E}+01$ \\
\hline Total & $1.96 E+01$ & $7.25 E+11$ & $\ldots$ & & & $6.70 E+01$ \\
\hline
\end{tabular}

- Assume 18,000 L, $1 \mathrm{~g} / \mathrm{cc}$; data provided by M. Hall, 02/22/96.

** Fissile isotopes; total fissile mass $=41.6 \mathrm{~g}$.

\subsection{CLASSIFICATION}

To meet the definition of LSA-II, the specific activity of a liquid cannot exceed $10^{-5} \mathrm{~A}_{2} / \mathrm{g}$. This will be true if the number of $\mathrm{A}_{2} \mathrm{~s}$ in the 1 iquid divided by $10^{-5}$ and the mass of the material is less than 1 . This is represented as: 
WHC-SD-TP-SEP-048 Rev. 0

$$
\frac{\text { Number of } A_{2} s}{10^{-5} \times \text { mass }(g r a m s)}<1
$$

There are $67 \mathrm{~A}_{2} \mathrm{~s}$ per shipment; the minimum mass of the liquid equals $1.51 \times 10^{07} \mathrm{~g}$. The mass is calculated by multiplying the maximum volume of liquid, $1.514 \times 10^{07} \mathrm{~cm}^{3}(15,140 \mathrm{~L}[4,000 \mathrm{gal}])$, by the minimum density of the waste, $1.0 \mathrm{~g} / \mathrm{cm}^{3}$. The resulting equation is

$$
\frac{67}{10^{-5} \times 1.51 \times 10^{7}}=0.444
$$

The result is less than one. There are less than $100 \mathrm{~A}_{2} \mathrm{~s}$, the dose rate is less than $1000 \mathrm{mrem} / \mathrm{h}$ at $3 \mathrm{~m}$ from unshielded material (See Part $B$, Section 5.0), and the radioactive contents are essentially uniformly distributed. The shipment meets all LSA-II requirements.

The liquid is fissile excepted per 49 CFR $173.453(\mathrm{~b})$ because it is a homogenous mixture that has less than $5 \mathrm{~g}(0.18 \mathrm{oz})$ of fissile material per liter, a mass of fissile radionuclides less than $500 \mathrm{~g}(17.64 \mathrm{oz})$, and a ratio of hydrogen atoms to fissile atoms greater than 5200. All these requirements were exceeded by at least a factor of 10 . The liquid is also fissile excepted per 49 CFR 173.453 (d) because the concentration of fissile radionuclides in any $10-L$ volume is less than $5 \mathrm{~g}(0.18 \mathrm{oz})$ per liter and will maintain the limitation on fissile radionuclide distribution during normal transfer conditions.

\subsection{REFERENCE}

49 CFR 173, 1996, "Packaging and Transportation of Radioactive Material", Code of Federal Regulations, as amended. 
WHC-SD-TP-SEP-048 Rev. 0

\subsection{CONTAINMENT EVALUATION}

\subsection{INTRODUCTION}

The purpose of this evaluation is to determine the ability of the 222-5 Cargo Tank and LETF Cargo Tanks to maintain their contents under onsite normal transfer conditions.

\subsection{CONTAINMENT SOURCE SPECIFICATION}

The authorized payload is described in Part B, Section 2.0.

\subsection{NORMAL TRANSFER CONDITIONS}

The containment boundary is provided by the stainless steel two-piece barrel and heads. Penetrations are provided on the top of the containment vessel for installation of the manhole cover, rupture disc, relief valve, pressure gauge, ball valve, coupler, and dip tubes. These penetrations with the installed components include bolted flanges with neoprene gaskets to seal the containment boundary. During transport of the loaded cargo tank, the valves are closed.

\subsubsection{Conditions To Be Evaluated}

The conditions to be evaluated for normal transfer conditions are structural integrity, thermal performance, and pressurization.

\subsubsection{Release Acceptance Criteria}

Acceptable performance is defined as the ability of the MC-312 Cargo Tank to survive normal transfer conditions with no significant yielding of the cargo tank materials of fabrication and no loss of function due to thermal conditions or pressurization.

\subsubsection{Containment Evaluation}

The structural evaluation in Part 8 , Section 5.0, evaluated the $M C-312$ Cargo Tanks to their original DOT specification, IP-2 requirements, and specific normal transfer conditions. Results of the evaluation indicate the cargo tanks meet these requirements, and no yielding of material of fabrication would occur. The MC-312 Cargo Tanks are American Society of Mechanical Engineers (ASME) certified and have a certificate of compliance $(\mathrm{COC})$ from the vendor.

A thermal evaluation of the MC-312 Cargo Tanks is presented in Part B, Section 6.0. This evaluation concluded that, because of the low payload heat generation, the materials of fabrication are adequate for the temperature range of $-33^{\circ} \mathrm{C}\left(-27^{\circ} \mathrm{F}\right)$ and $46^{\circ} \mathrm{C}\left(115^{\circ} \mathrm{F}\right)$ for the Hanford environment. 
The pressure and gas generation analysis presented in Part B, Section 6.0 , demonstrated that the pressure increase would be very small and would be much less than the design pressure of $476 \mathrm{kPa}$ (40 psi) for the MC-312 Cargo Tank.

\subsection{CONTAINMENT EVALUATION AND CONCLUSIONS}

The MC-312 Cargo Tank containment for normal transfer conditions is demonstrated to be adequate based on the structural, thermal, and gas generation evaluations. 


$$
\text { WHC-SD-TP-SEP-048 ReV. } 0
$$

\subsection{SHIELDING EVALUATION}

\subsection{INTRODUCTION}

The cargo tanks are limited to a maximum volume of $15,140 \mathrm{~L}(4,000 \mathrm{gal})$ per shipment. The payload will contain LSA-II shipments up to $67 \mathrm{~A}_{2} \mathrm{~s}$ of radioactive material. Based on the cargo tank evaluation, up to $100 \mathrm{~A}_{2} s$ of radioactive material will be authorized. LSA-II liquid material is defined in 49 CFR 173.403 (1996) as liquids containing less than $10^{-5} \mathrm{~A}_{2} / \mathrm{g}$.

\subsection{DIRECT RADIATION SOURCE SPECIFICATION}

\subsubsection{Gamma Source}

The gamma source term used in the shielding analysis was taken from Part B, Section 2.0, and is listed in Table B4-1.

\subsubsection{Beta Source}

The beta source within the cargo tank leads to an insignificant dose rate outside the tank because of the shielding provided by the tank. This shielding, consisting of steel, is described in Part B, Section 4.4.3.

\subsubsection{Neutron Source}

All the actinides listed in Table B4-1 will fission spontaneously. The total neutron source strength from spontaneous fission was computed to be $3.6 \times 10^{2}$ neutrons/s. The concentration of fissile material is very low, so neutron multiplication will also be low (Part B, Section 6.0). The neutron dose rate was estimated using the methods described in Estimation of Neutron Dose Rates from Nuclear Waste Packages (Nelson 1996) and was found to be insignificant compared to the gamma dose rate. Therefore, the neutron dose rates are not reported.

\subsection{SUMMARY OF SHIELDING PROPERTIES OF MATERIALS}

The shielding attenuation properties for the bulk materials used in this analysis were obtained from the ISO-PC data library (Rittmann 1995). A description of the configuration and densities of the shielding materials used in the calculational models is given in Part B, Section 4.4.3. 
Table B4-1. 222-S Cargo Tank Source Term.

\begin{tabular}{|l|c||l|c|}
\hline \multicolumn{1}{|c|}{ Nuclide } & $\begin{array}{c}\text { Maximum cargo tank } \\
\text { activity (Ci) }\end{array}$ & Nuclide & $\begin{array}{c}\text { Maximum cargo tank } \\
\text { activity (Ci) }\end{array}$ \\
\hline${ }^{3} \mathrm{H}$ & $8.40 \mathrm{E}-01$ & ${ }^{154} \mathrm{Eu}$ & $5.54 \mathrm{E}-03$ \\
\hline${ }^{14} \mathrm{C}$ & $6.50 \mathrm{E}-03$ & ${ }^{231} \mathrm{Th}$ & $8.50 \mathrm{E}-05$ \\
\hline${ }^{60} \mathrm{Co}$ & $4.35 \mathrm{E}-01$ & ${ }^{238} \mathrm{Pu}$ & $2.15 \mathrm{E}-02$ \\
\hline${ }^{90} \mathrm{Sr}$ & $2.63 \mathrm{E}+00$ & ${ }^{239} \mathrm{Pu}$ & $1.85 \mathrm{E}-01$ \\
\hline${ }^{90} \mathrm{Y}$ & $2.63 \mathrm{E}+00$ & ${ }^{241} \mathrm{Am}$ & $1.45 \mathrm{E}-01$ \\
\hline${ }^{99} \mathrm{TC}$ & $5.50 \mathrm{E}-02$ & ${ }^{234} \mathrm{U}$ & $1.45 \mathrm{E}-02$ \\
\hline${ }^{129} \mathrm{I}$ & $4.80 \mathrm{E}-02$ & ${ }^{235} \mathrm{U}$ & $8.50 \mathrm{E}-05$ \\
\hline${ }^{137} \mathrm{CS}$ & $2.61 \mathrm{E}+00$ & $238 \mathrm{U}$ & $1.40 \mathrm{E}-03$ \\
\hline${ }^{137 \mathrm{~m} B}$ & $2.47 \mathrm{E}+00$ & Total & $1.96 \mathrm{E}+01$ \\
\hline${ }^{147} \mathrm{Pm}$ & $7.50 \mathrm{E}+00$ & \multicolumn{2}{|c}{} \\
\hline
\end{tabular}

\subsection{NORMAL TRANSFER CONDITIONS}

\subsubsection{Conditions To Be Evaluated}

Dose rates are evaluated at the container surface, at $2 \mathrm{~m}$ from the surface, and $2 \mathrm{~m}$ from the end of the container, the assumed distance to the nearest normally occupied space. In addition, the dose rate at $3 \mathrm{~m}$ from unshielded material will be evaluated for LSA transport requirements.

\subsubsection{Acceptance Criteria}

The shielding acceptance criteria for normal transfer conditions are a maximum of $200 \mathrm{mrem} / \mathrm{h}$ on any surface of the tank, $10 \mathrm{mrem} / \mathrm{h}$ at $2 \mathrm{~m}$ from the surface, and $2 \mathrm{mrem} / \mathrm{h}$ in any normally occupied space. In addition, the dose rate at $3 \mathrm{~m}$ from unshielded material must be less than $1,000 \mathrm{mrem} / \mathrm{h}$ to meet LSA-II criteria.

Based on the shielding analysis, the container surface dose rate limit is met; however, the dose rate limits at $2 \mathrm{~m}$ and the normally occupied space are exceeded. Justification to exceed these limits is provided in Part $B$, Appendix 4.7.2. Additional administrative controls are provided in Part $A$, Section 4.3.2, to address transport of the cargo tank with the estimated dose rates. 


$$
\text { WHC-SD-TP-SEP-048 Rev. } 0
$$

\subsubsection{Shielding Mode1}

The ISO-PC program (Rittmann 1995) was used for the gamma-ray dose rate calculations. ISO-PC uses the point-kernel integration method to compute the dose rate at a detector location. Bremsstrahlung photons are accounted for in the dose rate calculations. Fluence-to-dose conversion factors were based on an anterior-to-posterior irradiation pattern (ANSI 1991).

The tank container shell is constructed of 4.17-mm (8-gauge) 304 stainless steel with a $147-\mathrm{cm}$ (573-in.) diameter and 1,128-cm (444-in.) length. The heads (ends) are 4.76-mm (3/16-in.) 304 stainless steel and are butt welded to the two-piece shell. The source term consisted of the radioactivity listed in Table B4-1, which was assumed to be homogeneously distributed throughout the tank volume. The liquid waste was modeled as water with a density of $1 \mathrm{~g} / \mathrm{cc}$. The tank wall was modeled as iron with a density of $8.0 \mathrm{~g} / \mathrm{cc}$.

\subsubsection{Shielding Calculations}

Table B4-2 summarizes the gamma dose rate estimates from ISO-PC for various distances from the cargo tank surface. The maximum dose rate at the surface of the tank is estimated to be $73 \mathrm{mrem} / \mathrm{h}$ and is $13 \mathrm{mrem} / \mathrm{h}$ at $2 \mathrm{~m}$ from the surface of the tank. The dose rate at the approximate location of the driver is $5.1 \mathrm{mrem} / \mathrm{h}$. The maximum unshielded dose rate at $3 \mathrm{~m}$ is $14 \mathrm{mrem} / \mathrm{h}$. Example ISO-PC input decks are included in Section 4.7.

The dose rate for the cargo tank with the maximum anticipated radioactive loading meets the regulatory requirement of $200 \mathrm{mrem} / \mathrm{h}$ at the surface of the cargo tank. However, the dose rate of $13 \mathrm{mrem} / \mathrm{h}$ at $2 \mathrm{~m}$ from the cargo tank exceeds the $10-\mathrm{mrem} / \mathrm{h} 1 \mathrm{imit}$, and the dose rate of $5.1 \mathrm{mrem} / \mathrm{h}$ at the driver location exceeds the $2.0-\mathrm{mrem} / \mathrm{h}$ limit for any space normally occupied by personnel. Approximately $3 \mathrm{~cm}$ of steel is required to reduce the driver dose rate to $2.0 \mathrm{mrem} / \mathrm{h}$. The LSA transport dose rate 1 imit of $1,000 \mathrm{mrem} / \mathrm{h}$ at $3 \mathrm{~m}$ from the unshielded material is satisfied.

Table B4-2. Dose Rates (mrem/h) Outside the 222-S Cargo Tank.

\begin{tabular}{|l|c|c|}
\hline \multirow{2}{*}{ Distance from tank surface } & \multicolumn{2}{|c|}{ Tank surface } \\
\cline { 2 - 3 } & Side & End \\
\hline On surface & 71 & 73 \\
\hline 2 m & 13 & 5.1 \\
\hline Driver location* & NA & 5.1 \\
\hline Driver location* with 3-cm steel shield & NA & 1.9 \\
\hline 3 m from unshielded material & 14 & 3.9 \\
\hline
\end{tabular}

* Oriver assumed to be located 2 in from the end of the tank. 


\subsection{SHIELDING EVALUATION AND CONCLUSIONS}

Table B4-3 summarizes the results of the shielding analysis for normal operating conditions and for LSA-II determination. The dose rate for the cargo tank with the maximum anticipated radioactive loading meets the requirements of $200 \mathrm{mrem} / \mathrm{h}$ at the surface of the cargo tank. However, the dose rate of $13 \mathrm{mrem} / \mathrm{h}$ at $2 \mathrm{~m}$ from the cargo tank exceeds the $10-\mathrm{mrem} / \mathrm{h} 7 \mathrm{imit}$, and the dose rate of $5.1 \mathrm{mrem} / \mathrm{h}$ at the driver location exceeds the $2.0-\mathrm{mrem} / \mathrm{h}$ limit for any space normally occupied by personnel. Approximately $3 \mathrm{~cm}$ (1.2 in.) of steel or $2 \mathrm{~cm}(0.8 \mathrm{in.})$ of lead is required to reduce the driver dose rate below $2.0 \mathrm{mrem} / \mathrm{h}$. The dose rate of $14 \mathrm{mrem} / \mathrm{h}$ at $3 \mathrm{~m}$ from the unshielded material is far below the 1,000-mrem/h limit for LSA-II material.

Table B4-3. Comparison of Maximum Dose Rates $(\mathrm{mrem} / \mathrm{h})$ With Regulatory Limits.

\begin{tabular}{|l|c|c|}
\hline \multicolumn{1}{|c|}{ Detector location } & Regulatory limit & Calculated \\
\hline \hline Normal operating Conditions & 200 & 73 \\
\hline On surface & 10 & 5.1 \\
\hline $2 \mathrm{~m}$ & 2 & 5.1 \\
\hline Driver location* & 2 & 1.9 \\
\hline Oriver location* with 3-cm steel shield & 1,000 & 14 \\
\hline $3 \mathrm{~m}$ from unshielded material & & \\
\hline
\end{tabular}

*Driver assumed to be located 2 m from the end of the tank.

To allow exceeding the 2-m distance and driver location dose rates, justification is provided in Section 4.7.2. Additional administrative controls are provided in Part $A$, Section 4.3.2, to address transport of the cargo tank with the maximum estimated dose rates.

\subsection{REFERENCES}

49 CFR 173, 1996, "Packaging and Transportation of Radioactive Material, " Code of Federal Regulations, as amended.

60 FR 50319, 1995, "Hazardous Materials, Transportation Regulations;

Compatibility With Regulations of the International Atomic Energy Agency

(IAEA); Final Rule," 49 CFR Part 171, Federal Register, Vol. 60, No. 188, PP. 50319-50325.

ANSI, 1991, Neutron and Gamma-ray Fluence-to-dose Factors, ANSI/ANS-6.1.1-1991, American National Standards Institute, New York, New York. 
Nelson, J. V., 1996, Estimation of Neutron Dose Rates from Nuclear Waste Packages, (internal memo 8M730-JVN-96-007 to J. R. Green, March 8), Westinghouse Hanford Company, Richland, Washington.

Rittmann, P. D., 1995, ISO-PC Version 1.98 - User's Guide, WHC-SD-WM-UM-030, Westinghouse Hanford Company, Richland, Washington.

\subsection{APPENDICES}

\subsubsection{Listings of Selected ISO-PC Input Files}

\section{Calculation of Radial Dose Rates under Normal Conditions}

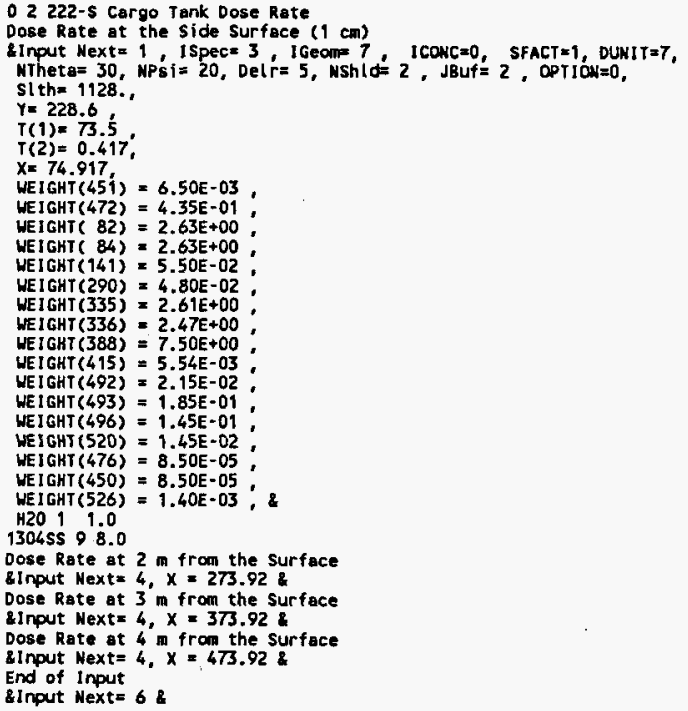


Calculation of Axial Dose Rates under Normal Conditions

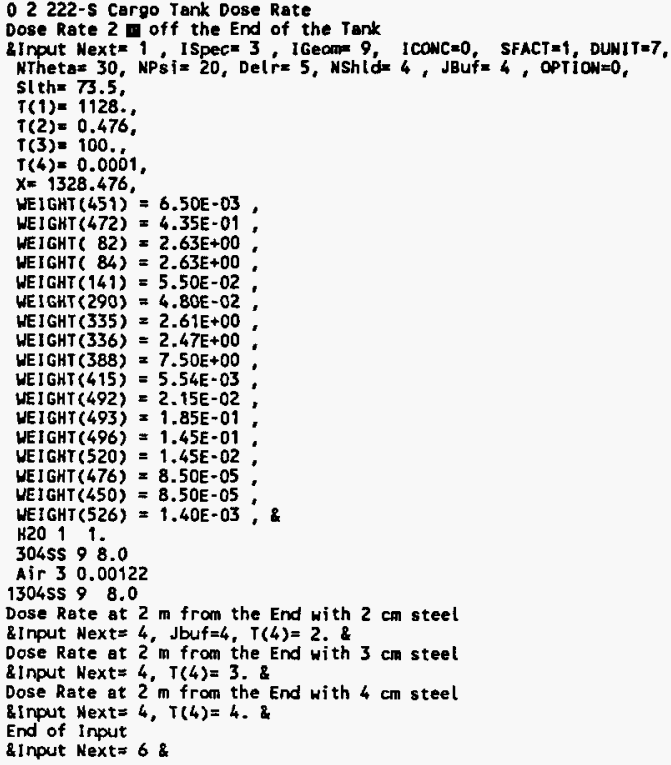

Calculation of Unshielded Material Radial Dose Rate under Normal Conditions

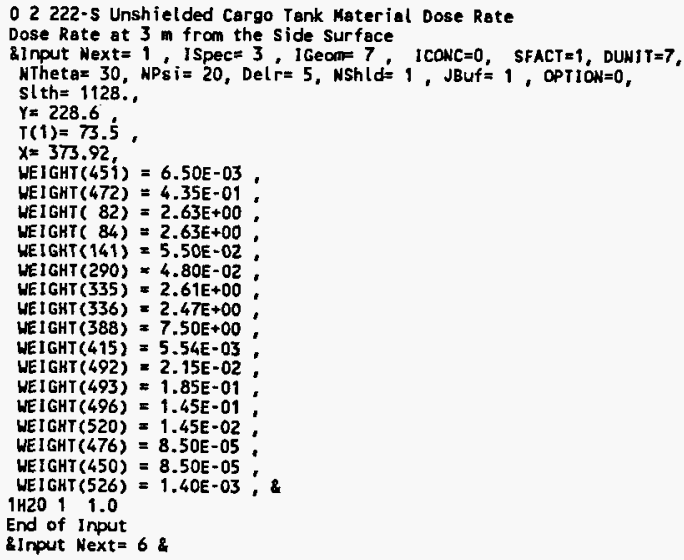


WHC-SD-TP-SEP-048 ReV. 0

\subsubsection{Justification for Exceeding $2-M$ and Driver Location Dose Rates}

Based on the MC-312 Cargo Tank source term, the shielding analys is estimated the maximum $2-m$ dose rate on the side and the maximum driver location dose rate as $13 \mathrm{mrem} / \mathrm{h}$ and $5.1 \mathrm{mrem} / \mathrm{h}$, respectively (refer to Table B4-2). These calculated dose rates exceed the DOT regulatory limits of $10 \mathrm{mrem} / \mathrm{h}$ and $2 \mathrm{mrem} / \mathrm{h}$, respectively. The maximum surface contact dose rate was estimated to be $73 \mathrm{mrem} / \mathrm{h}$, well below the DOT 1 imit of $200 \mathrm{mrem} / \mathrm{h}$. Justification to authorize transport of the cargo tank for the estimated dose rates for the 2-m distance and driver location is as follows.

From the sample analysis for liquids to be transferred from the facility, it is very difficult to predict the dose rates when the cargo tank is filled. It is conceivable that DOT dose rate limits may be exceeded.

For the 2-m distance, the maximum estimated dose rate of $13 \mathrm{mrem} / \mathrm{h}$ is only slightly above the $10-\mathrm{mrem} / \mathrm{h}$ limit. It would be very impractical to remove liquid from the cargo tank or install shielding on the cargo tank surface to reduce the dose rate to $10 \mathrm{mrem} / \mathrm{h}$. Shipment of smaller volumes to reduce the dose rate would increase the number of shipments, which would greatly impact facility operations and would not be cost effective. Performing all of these operations would increase exposure time to affected personne1; hence as 1ow as reasonably achievable (ALARA) practices would not be followed. To mitigate personnel exposure for the slightly higher 2-m dose rate, safety controls can be enacted by this document; hence establishment of a higher dose rate limit is justified.

For the driver location, shielding on the transport vehicle will be added, as needed, if the dose rate limit is exceeded. From the shielding analysis, $3 \mathrm{~cm}$ (1.2 in.) of steel or $2 \mathrm{~cm}(0.8 \mathrm{in}$.) of lead is sufficient to reduce the dose rate to the $2-\mathrm{mrem} / \mathrm{h}$ limit; hence establishment of a higher dose rate is justified. 


\subsubsection{Checklist for Peer Review}

\section{CHECKLIST FOR PEER REVIEH}

Document Reviewed: Shielding Analys is for the 222-S Cargo Tank SEP

Scope of Review: Entire shielding analysis - Section 5.0

Yes No NA

[ ] [ ] $[\mathrm{X}]$

[X] [ ] [ ]

[X] [ ] [ ]

$[x]=[]$

$[x][][]$

X] [ ] [ ]

[ ] [-] $\mathrm{X}$

[X] [ ] [ ]

[ ] [ ] [X]

$\infty][][]:$

D] [ ] [ ]

$\left[\begin{array}{lll}x] & {[}\end{array}\right][]$

[X] [ ] [ ]

Di] [ ] []

[ ] [女]

Previous reviews complete and cover analysis, up to scope of this review, with no gaps.

Problem completely defined.

Accident scenarios developed in a clear and logical manner.

Necessary assumptions explicitly stated and supported.

Computer codes and data files documented.

Data used in calculations explicitiy stated in document.

Data checked for consistency with original source information as applicable.

Mathematical derivations checked including dimensional

consistency of results.

Models appropriate and used within range of validity or use outside range of established validity justified.

Hand calculations checked for errors. Spreadsheet results should be treated exactly the same as hand calculations.

Software input correct and consistent with document reviewed. Software output consistent with input and with results reported in document reviewed.

Limits/criteria/guidelines applied to analysis results are appropriate and referenced. Limits/criteria/guidelines checked against references.

Safety margins consistent with good engineering practices. Conclusions consistent with analytical results and applicable limits.

Results and conclusions address all points required in the problem statement.

Format consistent with appropriate NRC Regulatory Guide or other standards

Review calculations, comments, and/or notes are attached.

L] [ ] [ ] Document approved.

Harvey Gold bera

Reviewer (Printed Name and Signature)

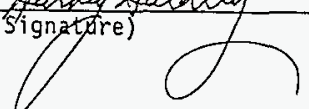


WHC-SD-TP-SEP-048 Rev. 0

\subsection{STRUCTURAL EVALUATION}

\subsection{INTRODUCTION}

This evaluation will determine the structural capabilities of the 222-S Cargo Tank and the LETF Cargo Tanks.

\subsection{STRUCTURAL EVALUATION OF PACKAGE}

\subsubsection{Structural Design and Features}

The 222-S Cargo Tank and LETF Cargo Tanks were fabricated to the MC-312 DOT specification 49 CFR 178.340 and 49 CFR 176.343 (1989). Each cargo tank is ASME certified and has a COC that states the cargo tank was designed, constructed, and tested in accordance with DOT Motor Vehicle Cargo Tank Specifications for cargo tanks used for the transportation of classified liquids. See Part A, Sections 2.0 and 5.0, for additional information on vessel design and fabrication.

\subsubsection{Mechanical Properties of Materials}

Table B5-1 shows material used in the Polar 5000 tank trailer.

Table B5-1. ASME Material Properties for

Section VIII, Division 1, Materials.

\begin{tabular}{|c|c|c|c|c|}
\hline $\begin{array}{c}\text { Material } \\
\text { composition use }\end{array}$ & Temperature & $\begin{array}{l}\text { Minimum } \\
\text { strength }\end{array}$ & $\underset{k s i}{F_{y}}$ & $\mathrm{SSI}_{\mathrm{TI}}$ \\
\hline $\begin{array}{l}\text { SA-240, } 304 \\
18 \mathrm{Cr}-8 \mathrm{Ni} \\
\text { (rings) }\end{array}$ & $\begin{array}{l}\leq 100^{\circ} \mathrm{F} \\
\leq 200^{\circ} \mathrm{F} \\
\leq 300^{\circ} \mathrm{F}\end{array}$ & $75 \mathrm{ksi}$ & $\begin{array}{l}30.0 \\
25.0 \\
22.5\end{array}$ & $\begin{array}{l}18.8 \\
17.8 \\
16.6\end{array}$ \\
\hline $\begin{array}{l}\text { SA-240, T316 } \\
\text { (sheli) }\end{array}$ & $\begin{array}{l}\leq 1000^{\circ} \mathrm{F} \\
\leq 200^{\circ} \mathrm{F} \\
\leq 300^{\circ} \mathrm{F} \\
\end{array}$ & $75 \mathrm{ksi}$ & $\begin{array}{l}30.0 \\
25.9 \\
23.4 \\
\end{array}$ & $\begin{array}{l}18.8 \\
17.7 \\
15.6 \\
\end{array}$ \\
\hline $\begin{array}{l}\text { SA-240, T316L } \\
\text { (heads) }\end{array}$ & $\begin{array}{l}\leq 100^{\circ} \mathrm{F} \\
\leq 200^{\circ} \mathrm{F} \\
\leq 300^{\circ} \mathrm{F} \\
\end{array}$ & $70 \mathrm{ksi}$ & $\begin{array}{l}25.0 \\
21.1 \\
19.0 \\
\end{array}$ & $\begin{array}{l}16.7 \\
16.7 \\
16.0 \\
\end{array}$ \\
\hline
\end{tabular}

*Source: ASHE. 1995, Section II, ASME Boiler and Pressure Vessel Cade, American Society of Mechanical Engineers, New York. New York (Tables $1 A$ and $Y-1$, Using the highest values of $s_{m \text {, }}$
allowing some permanent deformation). 


\subsubsection{Chemical and Gaivanic Reactions}

Because the cargo tank vessels are fabricated from T316, T316L, and 304 stainless steel, no chemical or galvanic reaction will affect the ability of the three MC-312 Cargo Tanks to maintain the payloads identified in Part $B$, Section 2.0. Other support systems are fabricated from various types of stainless steel. Neoprene gaskets installed on the bolted flanges would not be affected by the cargo tank chemical contents. The MC-312 Cargo Tank is approved by the DOT for commercial transport of a wide range of corrosive chemicals, such as caustics and acids. The $\mathrm{pH}$ of the liquid waste transported in the cargo tanks is normaliy between 10.5 to 13 for disposal into underground storage tanks, which is within the cargo tank design limits.

\subsubsection{Size of Package and Cavity}

See Part A, Section 2.0.

\subsubsection{Weights and Center of Gravity}

The center of gravity of a completely full MC-312 Cargo Tank $(18,925 \mathrm{~L}$ [5,000 gal]) is assumed to be at its geometric center. The cargo tank on its transporter is $133 \mathrm{~cm}$ (52.5 in.) above the ground. The coordinates of the center of gravity for the full MC-312 Cargo Tanks are:

$$
\begin{aligned}
& x--564 \mathrm{~cm}(222 \mathrm{in} .) \\
& y--73.5 \mathrm{~cm}(28 \% \text { in.) } \\
& z--206.5 \mathrm{~cm}(81 \% \text { in. })
\end{aligned}
$$

The cargo tank is capable of carrying the maximum liquid volume specified, a maximum load of $23,118 \mathrm{~kg}(50,965 \mathrm{lb})$. The cargo tank trailer is capable of carrying the cargo tank assembly; ancillary equipment; and the maximum liquid volume specified, a maximum load of $34,885 \mathrm{~kg}(78,000 \mathrm{lb})$.

\subsubsection{Tamper-Indicating Feature}

There are no tamper-indicating features. Due to the nature of the payload (low-level radioactive liquid waste), tamper-indicating features are not required. Operation of the valves on the cargo tanks is addressed by onsite lock and tag procedures.

\subsubsection{Positive Closure}

The containment boundary of the cargo tanks is provided with positive closure devices. Penetrations are provided on the top of the cargo tanks for installation of the manhole cover, rupture disc, relief valve, pressure gauge, ball valve, coupler, and dip tubes. These penetrations with the installed components include bolted flanges with neoprene gaskets to seal the containment boundary. During transport of the loaded cargo tank, the valves are closed. Operation of the valves on the cargo tanks is addressed by onsite lock and tag procedures. 
WHC-SD-TP-SEP-048 Rev. 0

\subsubsection{Lifting and Tiedown Devices}

Not applicable. The MC-312 Cargo Tanks are permanently secured to their transporter.

\subsection{NORMAL TRANSFER CONDITIONS}

\subsubsection{Conditions To Be Evaluated}

The three MC-312 Cargo Tanks are evaluated against the original cargo tank DOT specification (49 CFR 178.340 and 49 CFR 178.343 [1989]), IP-2 requirements (49 CFR 173.410 and 173.411 [1996]), and specific normal transfer conditions for the environment of the Hanford Site.

\subsubsection{Acceptance Criteria}

The radioactive materials that will be allowed to be transported will be based on the three MC-312 Cargo Tanks meeting the standards identified in Part B, Section 5.3.1, and shown in Part B, Section 5.3.3.

\subsubsection{DOT Specification Evaluation}

The three cargo tanks are evaluated against the applicable requirements for a DOT MC-312 Cargo Tank. The requirements are taken from 49 CFR 178.343 (1989). Each of the requirements is given, followed by a discussion of how each requirement is being addressed. The requirements and discussions are as follows.

49 CFR 178.343-1(a)

Specification MC-312 cargo tanks must comply with the general design and construction requirements in 178.340 in addition to the specific requirements contained in this section.

This requirement is met. The three cargo tank are ASME certified, and CoCs were issued by the vendor, certifying the cargo tanks were designed, constructed, and tested in accordance with DOT Motor Vehicle Cargo Tank Specifications for cargo tanks used for the transportation of classified liquids. Final inspection and testing of the cargo tanks were done by the vendor, Polar Tank Trailer, Inc., and witnessed by the Westinghouse Hanford Company (WHC) nondestructive examination personnel and ASME, the third-party inspector. The tests were documented in accordance with the procurement specification and are part of the QA data package.

\section{CFR 178.343-1(b)}

Tank Design: Cargo Tanks built under this specification that are unloaded by pressure in excess of 15 p.s.i.g. must be designed and constructed in accordance with and fulfill all requirements of the ASME Code. No tank shall have head, bulkhead, and baffle or shell thicknesses 
less than that specified in 178.343-2, Tables $I$ and II, nor shall the spacing of bulkheads, baffles, or shell stiffeners exceed that specified in 178.340-7.

This requirement is met. The cargo tanks were ASME certified.

49 CFR 178.343-1(c)

Design Pressure shall not be less than pressure used for unloading.

This requirement is met. The design operating pressure is $276 \mathrm{kPa}$ (40 psi). The cargo tanks were hydrostaticaliy tested at 1.5 times operating pressure and successfully passed this test. Normally, the cargo tank contents are removed using a vacuum transfer system.

$178.343-2(a)$

Material thickness: The minimum thickness of tank material authorized in 178.340-3 shall be predicated on not exceeding the maximum allowable stress level in 178.340-4(a) but in no case less than those indicated in Table I and II listed below, or the accompanying aluminum alloy formula: (1) Aluminum allow formula: Thickness of aluminum alloy materials = Steel thickness from Tables $I$ and $I I \times\left(3 \times 10^{7} / E\right)^{1 / 3}$ where $E=$ Modulus of Elasticity of the material to be used.

This requirement is met. The steel thicknesses for the two-piece barrel and heads of the cargo tanks meet the minimum thickness requirements of Tables I and II (refer to page 434 of 49 CFR 178.343 [1989]). The minimum steel thicknesses in Tables I and II for the MC-312 Cargo Tank are based on the volume capacity in gallons per inch (10 to 14), product weight in pounds per gallon ( 13 to 16$)$, maximum she11 radius in inches (less than 30), and overall steel sheet length in inches (less than 70). From the Tables, the minimum steel thickness required for the two-piece barrel is $4.17 \mathrm{~mm}$ ( 8 gauge) and for the heads is $4.76 \mathrm{~mm}(3 / 16 \mathrm{in}$.). The two MC-312 Cargo Tanks have a two-piece barrel of 4.17-mm (8-gauge)

thickness and heads of $4.76-\mathrm{mm}(3 / 16-i n$.$) thickness. The maximum stress$ levels will not be exceeded.

178.343-2(b)

Lining: Except as provided in paragraph (c). of this section, cargo tanks shall be lined and the material used for lining each cargo $t$ ank subject to this specification shall be homogeneous, nonporous, imperforate when applied, not less elastic than the metal of the tank proper, and substantially immune to attack by the commodities to be transported therein. It shall be directly bonded or attached by other equally satisfactory means. Joints and seams in the lining shall be made by fusing the material together, or by other equally satisfactory means.

The requirement is not applicable. The three MC-312 Cargo Tanks are not lined and are fabricated to the requirements of 178.343-2(c) (1989) for unlined tanks. 
Conditions under which tanks need not be lined: Tanks need not be lined as provided in paragraph (b) of this section, if: (1) The material of the tank is substantially immune to attack by the materials to be transported; or, (2) The material of the tank is thick enough to withstand 10 years normal service without being reduced at any point to less thickness than that specified in paragraph (a) of this section corresponding to its type; or, (3) The chemical reaction between the material of the tank and the commodity to be transported therein is such as to be properly passivated or neutralized and if the tank is not frequently cleaned and not used in the transportation of other commodities.

This requirement is met. The materials of the two-piece barrel and heads for the cargo tanks are $\mathrm{T} 316$ and $T 316 \mathrm{~L}$ stainless steel, which are immune to attack by the materials to be transported. The cargo tanks are designed for a minimum of 30 years of service.

178.343-3(a)

Each compartment shall be accessible through a manhole conforming to paragraph UG-46(g)(1) of the ASME Code. The manhole cover shall be designed to provide a secure closure of the manhole. All joints between manhole covers and their seats shall be tight against leakage of vapor and liquid. Gaskets, if used, shall be suitable material not subject to attack by lading. (1) The manhole cover shall have structural capability of withstanding internal fluid pressure equal to 1.5 times the design pressure of the tank and no case less than 15 p.s.i.g. without permanent deformation. Safety devices to prevent the manhole and/or fill cover from opening fully when internal pressure is present shall be provided.

This requirement is met. The cargo tanks are accessible through the top by a fully opening $50.8-\mathrm{cm}-(20-i n .-)$ diameter stainless steel manhole. A neoprene gasket is used to seat the manhole cover to prevent leakage of vapor and liquid and would not be affected by the cargo tank chemical contents. The manhole and gasket are secured by hold-down devices to prevent opening when internal pressure is present. The cargo tanks with the manhole cover secured were hydrostatically tested at 1.5 times the design pressure of $276 \mathrm{kPa}(40 \mathrm{psi})$, and no permanent deformation of the manhole was observed.

$178.343-4$

Safety Vent: Every cargo tank compartment shall be equipped with suitable pressure relief devices as required by the ASME Code, or shall be fitted with suitable rupture discs in lieu of mechanical pressure relief valves. Such discs shall be designed to rupture at not to exceed 1.5 times the design pressure of the tank. If air inlet devices are provided, a relief valve shall have adequate capacity to limit tank pressure to 130 percent of design pressure at maximum inlet flow rate. such maximum limits to be included on the metal certification plate 
178.340-10(b). Air inlet lines if permanently connected to an air source shall be equipped with a check valve. Shutoff valves between the tank and relief valve or rupture disc are prohibited.

This requirement is met. Each cargo tank has a ASME-tested $5.1-\mathrm{cm}$ (2-in.) rupture disc with polyethylene drain tube located at the top center of the vesse1. The rupture disc is designed to release pressure at a maximum value of $242 \mathrm{kPa}$ ( $35 \mathrm{psi}$ ), below the 1.5 times the design pressure of the tank.

\section{$178.343-5(a)$}

Each outlet at or near the top of a tank, used for discharge of lading, must be equipped with a shutoff valve located as close as practical to the point of outlet from the tank. Each such outlet having its discharge end below the top liquid level in the tank must be equipped with an additional shutoff valve, blank flange, or sealing cap at the discharge end of the outlet.

This requirement is met. Each outlet is equipped with a two-way ball valve and a "Snap-Tight" dust cover.

178.343-5(b)

Except as provided in paragraphs (c) and (d), of this section; each bottom outlet must be equipped with a shutoff valve designed, installed and protected as follows: (1) Product piping must be protected in such a manner as to reasonably assure against the accidental escape of contents. Such protection must be provided by: (i) A shear section located outboard of each valve seat and within 4 inches of the vessel which will break under strain and leave the valve seat and its attachment to the vessel and the valve head intact and capable of retaining product. The shear section shall be machined in such a manner as to abruptly reduce the wall thickness of the adjacent piping (or valve) by at least 20 percent; or (ii) By suitable guards capable of absorbing a concentrated horizontal force of at least 8,000 pounds applied from any horizontal direction, without damage to the discharge piping which will adversely affect the product retention integrity of the discharge valve. (2) Each bottom outlet valve must be located inside the tank or immediately adjacent to the outlet point outside the tank. (i) The valve seat must be located inside the tank or within the welded flange, its companion flange, nozzle, or coupling at the point of outlet from the tank. (ii) Each bottom discharge valve must be equipped with a remote means to activate a valve closure manually from a point no less than 10 feet away. (3) In addition, a blank flange, sealing cap, or shutoff valve is required at the discharge end of the outlet.

This requirement is not applicable. The cargo tanks are not equipped with bottom outlets. Bottom outlets on DOT specification containers are not authorized for shipment of LSA liquids according to 49 CFR 173.427 (c)(2)(ii) (1996). 
178. 343-5(c)

A bottom opening for purposes other than lading discharge may be closed by a bolted blank flange at the tank shell. If any piping extends from such an opening, it must be fitted with a shutoff valve designed, installed and protected as described in paragraph (b)(1) of this section. In addition a supplemental closure is required at the discharge end of this piping.

This requirement is not applicable. The cargo tanks are not equipped with bottom outlets.

178.345-5(d)

Bottom outlet valves need not meet paragraph (b)(2)(ii) of this section when the cargo tank is transporting a corrosive liquid containing solids in suspension in sufficient quantity that settling may form a layer of solid material that may interfere with sealing of the valve seat.

This requirement is not applicable. The cargo tanks are not equipped with bottom outlets.

\subsubsection{Industrial Packaging 2 Evaluation}

The three cargo tanks are evaluated against the IP-2 requirements. The requirements are taken from 49 CFR 173.410 and 49 CFR 173.411 (1996). Each of the requirements are given, followed by a discussion of how each requirement is being addressed. The requirements and discussions are as follows.

$173.410(a)$

The package can be easily handled and properly secured in or on a conveyance during transport.

This requirement is met. The cargo tanks are permanently secured to their transporter.

$173.410(b)$

Each lifting attachment that is a structural part of the package must be designed with a minimum safety factor of three against yielding when used to 7 ift the package in the intended manner, and it must be designed so that failure of any lifting attachment under excessive load would not impair the ability of the package to meet other requirements of this subpart. Any other structural part of the package which could be used to lift the package must be capab7e of being rendered inoperable for lifting the package during transport or must be designed with strength equivalent to that required for lifting attachments.

This requirement is not applicable. The cargo tanks are permanently secured to their transporter, and no lifting is done. 
WHC-SD-TP-SEP-048 ReV. 0

$173.410(\mathrm{c})$

The external surface, as far as practicable, will be free from protruding features and will be easily decontaminated.

This requirement is met. The cargo tank two-piece barrel, heads, and rings are constructed of T316, T316L, and 304 stainless stee 1 , which can be easily decontaminated. The cargo tank platform and various ancillary equipment, which are primarily on top of the tank, are constructed of various types of stainless steel and are also easily decontaminated.

\section{$173.410(d)$}

The outer layer of packaging will avoid, as far as practicable, pockets or crevices where water may collect.

This requirement is met. The cargo tanks on their external surfaces do not have attached equipment where water may collect.

$173.410(e)$

Each feature that is added to the package will not reduce the safety of the package.

This requirement is met. The cargo tanks do not have any features that will reduce the safety of the package.

\section{$173.410(f)$}

The package will be capable of withstanding the effects of any acceleration, vibration, or vibration resonance (see 178.608 of this subchapter) that may arise under normal conditions of transport without any deterioration in the effectiveness of the closing devices on the various receptacles or in the integrity of the package as a whole and without loosening or unintentionally releasing the nuts, bolts, or other securing devices even after repeated use (see 173.24 and 173.2a).

This requirement is met. This specification contains a load combination of dead weight (tank, contents, and equipment supported by the tank); internal pressure; $0.7 \mathrm{~g}$ vertical acceleration; and $0.75 \mathrm{~g}$ longitudinal acceleration. The stress intensity must remain under the ASME (1992) design limit under this loading. An evaluation using this criteria, included in Part B, Section 5.6, gives assurance of performance under loads, acceleration, and vibration incident to normal transfer conditions.

$173.410(\mathrm{~g})$

The materials of construction of the packaging and any components or structure will be physically and chemically compatible with each other and with the package contents. The behavior of the packaging and the packaging contents under irradiation will be taken into account.

This requirement is met. See Part B, Section 5.2.3. 


$$
\text { WHC-SD-TP-SEP-048 ReV. } 0
$$

\section{$173.410(h)$}

All valves through which the package contents could escape will be protected against unauthorized operation.

This requirement is met. Operation of the cargo tank valves is addressed by onsite lock and tag procedures. When not in use, the cargo tanks are located inside a locked, fenced area preventing access.

$$
173.411(b)(2)
$$

Each IP-2 must meet the general design requirements prescribed in 173.410 and when subjected to the tests specified in $173.465(c)$ and (d) or evaluated against these tests by any of the methods authorized by 173.461 (a), must prevent: (i) Loss or dispersal of the radioactive contents; and (ii) A greater than $20 \%$ increase in the radiation levels recorded or calculated at the external surfaces for the condition before the test.

The three MC-312 Cargo Tanks meet the safety intent of the IP-2 requirements. As discussed previously, the cargo tanks meet the general design requirements of 173.410 . The cargo tanks meet the intent of the tests specified in $173.465(\mathrm{c})$ and (d), and discussion related to these test requirements is as follows.

The tests specified in $173.465(\mathrm{c})$ and (d) constitute a $0.3-\mathrm{m}(1-\mathrm{ft})$ free drop and a compression test with five times the weight of the actual package. The cargo tank is permanently secured to its transporter. During normal operating conditions, the potential for a free drop of the cargo tank is not plausible. In the highly unlikely event of the free drop, damage to the cargo tank would be minimal due to the trailer suspension. Because the cargo tank penetrations are located on the top of the vessel and the orientation of a free drop would occur on the bottom or sides of the vessel, damage to these penetrations would be minimal, and loss of contents most likely would not occur. The compression test is normaliy conducted to evaluate stacking of packages. There will no operating condition where the cargo tank would be stacked to experience five times its actual weight.

Each MC-312 Cargo Tank with its transporter thus provides the safety features of an IP-2 package and is further defined as a conveyance for onsite transport of radioactive materials.

\subsubsection{Normal Transfer Conditions Evaluation}

The three MC-312 Cargo Tanks are evaluated for their ability to maintain containment and shielding when subjected to normal transfer conditions.

5.3.5.1 Environmental Conditions. The three MC-312 Cargo Tanks were evaluated to the conditions of the Hanford Site specified in the Environmental Conditions for On-Site Hazardous Materials Packages (WHC 1992). Results of this evaluation are provided in Part B, Section 6.0, "Thermal Evaluation." 
The evaluation demonstrates that containment and shielding for the loaded MC-312 Cargo Tanks are maintained during transport under the prescribed Hanford environmental conditions.

5.3.5.2 Maximum Operating Pressure. The design pressure of the cargo tanks is $276 \mathrm{kPa}$ (40 psi). The cargo tanks are equipped with 242-kPa (35-psi) rupture disc and relief valves. The cargo tanks were hydrostatically tested at $414 \mathrm{kPa}$ (60 psi).

5.3.5.3 Vibration. The MC-312 Cargo Tanks are designed to meet the norma] vibration due to transportation on the Hanford Site. See Part B, Section 5.3.4, for discussion of acceleration, vibration, and vibration resonance effects on the cargo tanks as related to the general packaging requirement of $173.410(f)$.

5.3.5.4 Water Spray. The test simulates exposure to rainfall at approximately $5.1 \mathrm{~cm}$ (2 in.) per hour for at least one hour. Penetrations on the top of the cargo tanks for the manhole, gauges, valves, and rupture disc have bolted flanges with neoprene gaskets, which provide adequate sealing capability. When not in operation, the valves are locked and tagged. The containment barrier of the cargo tanks through the penetrations will not be compromised due to the effects of rainfall.

5.3.5.5 Penetration. The test drops a bar $3.2 \mathrm{~cm}(1.25 \mathrm{in.})$ in diameter with a hemispherical end, weighing $6 \mathrm{~kg}(13.2 \mathrm{lb})$, with its longitudinal axis vertical onto the center of the weakest part of the packaging, to determine if the containment barrier is penetrated. The bar must not be deformed by the test. A penetration analys is was conducted (Part B, Section 5.6) and demonstrated that the cargo tank containment barrier will not be penetrated.

\subsection{STRUCTURAL EVALUATION AND CONCLUSIONS}

The MC-312 Cargo Tanks will be loaded with up to $15,140 \mathrm{~L}$ (4,000 gal) of bulk liquids. The MC-312 Cargo Tanks are capable of transporting a maximum gross weight of $23,118 \mathrm{~kg}(50,965 \mathrm{lb})$, and the trailers are capable of carrying a maximum gross weight of $34,885 \mathrm{~kg}(78,000 \mathrm{lb})$. The $\mathrm{MC}-312$ Cargo Tanks were evaluated to requirements from their original DOT specification, IP-2 requirements, and normal transfer conditions, and it was demonstrated that the MC-312 Cargo Tanks meet the safety intent of these requirements.

\subsection{REFERENCES}

49 CFR 173, 1996, "Packaging and Transportation of Radioactive Material", Code of Federal Regulations, as amended.

49 CFR 178.343, 1989, "Specification MC-312; Cargo Tank," Code of Federal Regulations.

49 CFR 178 Subpart J, 1989, "Specifications for Containers for Motor Vehicle Transportation," Code of Federal Regulations. 
ASME, 1995, Section II, ASME Boiler and Pressure Vessel Code, American Society of Mechanical Engineers, New York, New York.

ASME, 1992, Section VIII, Division 1, ASME Boiler and Pressure Vessel Code, American Society of Mechanical Engineers, New York, New York.

WHC, 1992, Environmental Conditions for On-Site Hazardous Haterial Packages, WHC-SD-TP-RPT-004, Rev. 0, Westinghouse Hanford Company, Richland, Washington.

\subsection{APPENDIX: STRUCTURAL AMALYSIS}




\section{DESIGN CALCULATION}

(1) Drawing

(4) Building

(2) Doc. No.

(5) Rev.

(3) Fage $i$

(7) Subject $222 \&$ CARGO TALK - STRUGTURAL

(8) Originator Wi= W.

(9) Checker

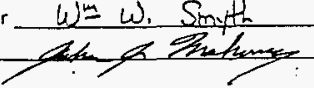

(6) Job No.

(10) For 2 MC312 tonks, find the following:

A. max. payload weight

3 tank deadlood stresses

$\subseteq$ Puncture resistance

References

Bechtel, 1974 : TORTC REAT 3C-TOP-EA, REV 2, DESIGN OF STRUCTURES FOR MISSILE IMPACT. SECHTEL POWER COEP

80kRk, bth: Reork's Furmulos for Sticss $\frac{c}{2}$. Stiwin, warren $C$. Young Mogtan Hil, 198?

Results \& Conclusions

A. The tank weight sapocity is limited by the trailer payload copacity of 51,000 lif. Using 4000 gallons as on odministrative limit, the loding is limited to a Sp.G. of 1,53

$B$ WHEN FULED WITH $51,000^{\circ}$ OF LIQUID 2 SUSUECTEO TD THE $\because$ MC 412 LOAD COMBNATIONS, INCLUDINE .75J LONGITUDINAL ACCELCRATON, .7G VERTICAL INAACT, AND 40 PSI INTRUAL PRESSLRE, DHE STEESS INTENSHY IS LESS THAN THE ASHE DESKN STEESS

$80.6400 .060 .1(12 / 87)$ 
WHC-SD-TP-SEP-048

Rev. 0

DESIGN CALCULATION

(1) Drawing

(2) Doc No. (3) Page $i \dot{z}$ of

(4) Building (5) Rev. (6) Job No.

(7) Subject 222.5 CAR CO TAUK - STRUCTURAL

(8) Originator UM S Date $6 / 24196$

(9) Checker Dote $9 / 2 / 96$

(10)

C. Using tho modified BRL formula, the standard - puncture test bor would penetrate .0218" but not $.027 "$. The tank wall is $164^{\prime \prime}$, so there is adequate margin for puncture resistance. Since the BRL was based on high speed missile impact, and the contact diameter used in the formula is arbitrary, a simplified impact energy based on a point-looded cylinder was used. This found stress just aver yield, demonstrating that the standard puncture bar will produce limited local deformation but no puncture,

$50.6400-060.1(12787)$

B5-13

BEST MUIIARE COPY 
WHC-SD-TP-SEP-048 Rev. 0

DESIGN CALCULATION

(1) Drawing

(2) Doc. No.

(3) Page of 8

(4) Building

(5) Rev. (6) Job No.

(7) Subject $222 \mathrm{~S}$ CARGO TANK

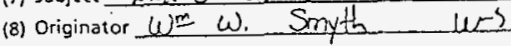

(9) Checker Date 12 June 96 Date $\& / 2 / 4 Z$

(10) using. Polar spec (copy attached), the tent is designed

(A) for $5000 \mathrm{gal}$ of liquid $e 16$ F/gal max, but the trailer payload rapacity is 51,000 bf. Find the max payload density corresponding $\frac{1}{10} 4,000$ gal $\& 51,000^{*}$

$$
\begin{array}{rl}
\frac{1}{1} 000 \mathrm{gal} & * \frac{231}{1728}=534.7 \mathrm{ft}^{3} \\
\text { density } & =\frac{51,000}{534.7}=95.38 \neq / \mathrm{ft}^{3} \\
\text { Sp.G. } & =\frac{55.4}{62.4}=1.53
\end{array}
$$

SARP should allow a maximum lord of $4,000 \mathrm{gal} e s_{p} .6$. of $15 \mathrm{~s}$

(B) Find the maximum trailer dead load stresses with 51,000* payload \&' 40 psi internal pressure.

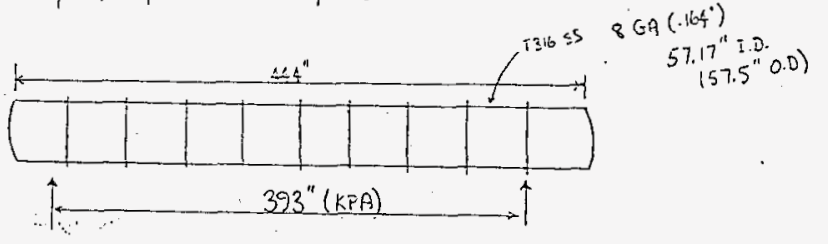

$$
\begin{aligned}
& \text { Long. Stress } \sigma_{a}=\frac{p \cdot \pi r^{2}}{2 \pi r t}=\frac{p r}{2 t} \\
& p=\text { int. pressure } \\
& r=\text { radius } \\
& t=\text { thickness }
\end{aligned}
$$

$$
\sigma_{a}=\frac{40(57.5 / 2)}{2 \cdot 0.164}=3506.25 i
$$

ED- $6400.060 .1(12 / 8)$

B5-14

BEST AVQHABIE COPY 
WHC-SD-TP-SEP-048 ReV. 0

DESIGN CALCULATION

(1) Drawing

(4) Building

(7) Subject

(8) Originator

(9) Checker

(10)

(Bat)

(2) Doc. No. (5) Rev. (3) Page 2 of 8 (6) Job No. 222 -S CARGO TALK Date $6 / 29 / 96$ Date $8 / 2 / 96$

circumf. sties $\sigma_{c}=\frac{p r}{t}=\frac{40(575 / 2)}{0.164}$

$=7012 \mathrm{Psi}$

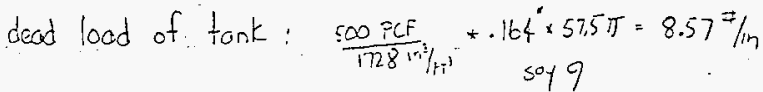

static ut of contents $\frac{51,000}{444^{11}}=\frac{115^{\frac{1}{1} / \mathrm{m}}}{124 \mathrm{H} / \mathrm{m} \mathrm{kngth} \text {. }}$

Treat the cylinder as a simple beam with supports e $393^{\circ}$ - ignore end moments clue to overhang.

moment e center $=\frac{1}{8}(124)(393)^{2}=2.393, \% 0 \%-\mathrm{in}$.

add effect of $1000^{\$}$ platform : $\frac{1}{4}(1000)(393)=\frac{98,250-\text { see P } 3}{2,492,0004}$

section modulus of a thin ring is $\frac{2,250}{2,492,000} \neq 1 "$

$$
S_{x}=\frac{\pi t d^{2}}{4}=\frac{\pi(.164)(57.5)^{2}}{4}=426 \mathrm{in}^{3}
$$

beam bending stress $f_{b}=\frac{M}{S_{x}}=\frac{2492,000}{426} \cdot 5850$ psi

stress intensity : 40 psi $S I=7012-3506=3506$ psi

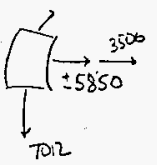

$$
\text { beam bending } \begin{aligned}
S I & =5850+3006-7012 \\
& =2340 \text { psi e bottom }
\end{aligned}
$$

top $S I=7012-(-5850+3506)=9360$

BD $64000.060 .1(12 ; 87)$

B5-15

BEST SUABLE COPY 


\section{DESIGN CALCULATION}

(1) Drawing (2) Dor. No.

(4) Building (5) Rev. (3) Page 3 of 8

(7) Subject

(8) Originator 222-5 CARTO TANK

(9) Checker (ur) (6) Job No.

(10) Find the weight of the work platform: Ref PR 32750,

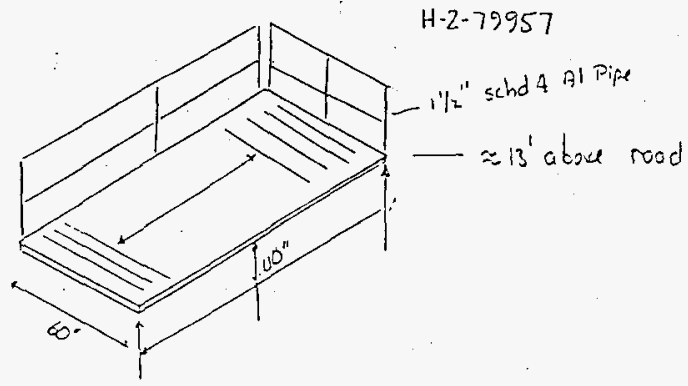

Estimate. He platform weight - it was added by Polar at the direction of $=032750$ - no materials noted.

Floor $R_{L}$ : essume SS $R \quad 9 / 8$ "TK $\frac{110 \times 60 \times 3 / 8}{1728}+500 \frac{16}{4^{3}}=7167$ Floor Beam: assume L $2 \times 2.1 / 4: \frac{2}{12}(\underbrace{60+110}) \times 3.2 \%=91^{\circ}$

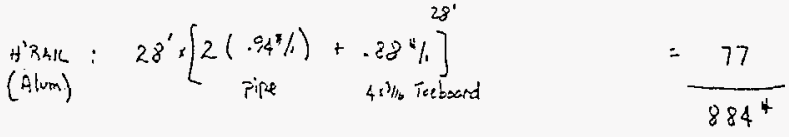
This platform is attached to 3 rings neor the center of the tonk 


\section{DESIGN CALCULATION}

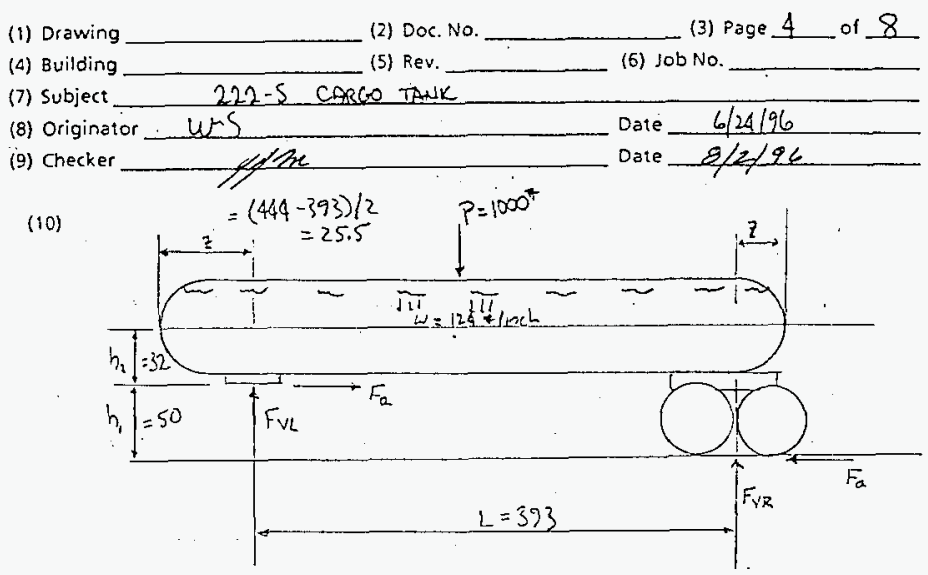

MC 412 spec trailers replace MC 312. 49 CFR 178.345-3 provides design loods that must be mat with a primory membrane stress $\leq . S_{n}$, from ASME section DIf, div. 1$S_{m}$ is $17.7 \mathrm{kS} 1$ \& $200^{\circ} \mathrm{F}$ [Ass.e. 1994]. The following loods ore combined: (MAwp or lowest pressure), (bendivg due to loding, tonk weight. $\xi$ tonk-manited equipment, ), $(.75 \times$ vertical-reaction $\{$ call this $.75 \mathrm{~g}\}$ accelerative or decelerative force opplied at the road surfoce), ( $\pm .75 \mathrm{~g}$

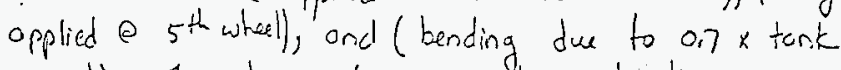
weight). The sheor stresses in the combination are not importent since the maximum kending stress occur in the center of the tank, whese sheor is vany low. Approximate $h_{2}$ based on the tank rodius and $5^{\text {th }}$ wheal thickress, and simplify the model by using equal overtiongs at both ends 
WHC-SD-TP-SEP-048 Rev. 0

DESIGN CALCULATION

(1) Drawing

(4) Building

(7) Subject

(8) Originator

(9) Checker
(2) Doc. No.

(5) Rev.

222-5 CARCO TALK

or uss

(10) The maximum shear stress is bounded by

$$
\begin{aligned}
\tau=\frac{2 V}{A} \quad V & =393 \times \frac{124 t 11}{2} * 1.7=41.420 \mathrm{bf} \\
A & =\pi d t=\pi(57.75)(.164) * 29.75
\end{aligned}
$$

$\tau_{\text {max }}=2785$ si e support points, ignoring overhang.

The worst combination is : 40 psi pressure; $.75 \mathrm{~g}$ forward acelleration and $7 \mathrm{~g}$ vertical acelleration. Tank axial fore $=40$ psi $*$ area $+.75 \times$ wt of water

$$
\begin{aligned}
& =40\left(\pi i 57.75^{2} / 4\right)+.75 \times \frac{62.4725}{1728} \times 444 \times \pi .57 .75^{2} / 4 \\
& =104,800+31,500=136,300 \mathrm{kf}
\end{aligned}
$$

axial stress due to pressure $\xi_{i}$ acellerting water

$$
\frac{136,300}{\pi(57.75)(164)}=4580 \mathrm{psi}
$$

circumferential stress duse to 40 psi: 7043

$$
\begin{aligned}
& F_{a}=-.75(124 \times 44+1000) / 2=-21,020 \\
& F_{v_{L}} \quad \quad 1.7(124 \times 444+1000) / 2+21,020 \cdot 50 / 393=50,320
\end{aligned}
$$

max moment $c$ "x "from left end: point of o stew

$$
50,320=1,7 \times 124 x=0 \quad x=239^{\prime \prime}
$$

BD -6400-060.1 (12.87)

B5-18

BEST MWmEMELE COPY 


\section{DESIGN CALCULATION}

(1) Drawing

(4) Building (2) Doc. No.

(3) Page 6 of 8

(7) Subject

(5) Rev.

(6) Job No.

(8) Originator wes

(9) Checker 222.5 CARGO TAKL

Date $\quad 6 / 24196$

(10)

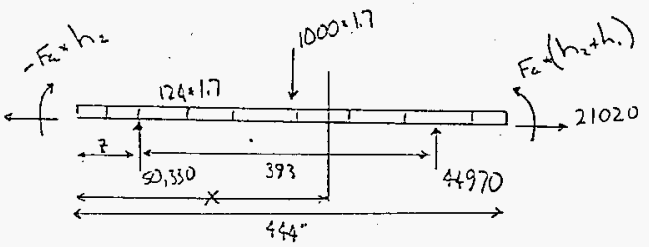

$$
\begin{aligned}
\text { max Moment }=-F_{a} \cdot h_{2} & +50,330(: x-z)-1.7 \times 124(x)^{2} / 2 \\
& -1000\left(x-\frac{444}{2}\right)=5,381,000 \neq
\end{aligned}
$$

$$
\begin{aligned}
& \text { bending stress }= \pm \frac{M}{S_{x}}= \pm \frac{5,381,000}{426}=12,630 \\
& \text { + bottom } \\
& \overbrace{1}^{.043}\left(\begin{array}{l}
17210 \text { bottom } \\
-8050 \text { top }
\end{array}\right. \\
& \text { - top } \\
& \text { Top } S I=|7040-(-8000)| \\
& =15,000 \mathrm{psi} \\
& \text { botham SI }=|7040-17,210| \\
& =10,170 \mathrm{ps} i
\end{aligned}
$$

$\max S I<17,700$ 
WHC-SD-TP-SEP-048

Rev. 0

DESIGN CALCULATION

(1) Drawing

(2) Doc. No

(3) Page 7 of 8

(4) Building

(5) Rev. (6) Job No.

(7) Subject 221_ CAB V 20 TANK

(8) Originator wi Date $66 / 24196$

(9) Checker Date $8 / 2 / 96$

(10) [c] Find the puncture resistance: acceptance criteria:

No penetration by a $6 \mathrm{~kg}$ steel cylinder, $3.2 \mathrm{~cm}$ diameter with a hemispherical end, dropped $1 \mathrm{~m}$.

[Bechtel, 1974]. was a modified Ballistic Research Lab formula to calculate the minimum steel thick ios! " $T$ " penetrated by a missile, then recommends using $1,25 T$ to resist penetration

$$
\begin{aligned}
& T=\frac{\left(\frac{M V_{3}^{2}}{2}\right)^{2 / 3}}{672 D} \\
& M=\text { missile moss, } b \mathrm{scc}^{2} / \mathrm{ft} \\
& V_{s}=\text { normal striking velocity } \\
& \text { ftisine } \\
& D=\text { missile diomater, in }
\end{aligned}
$$

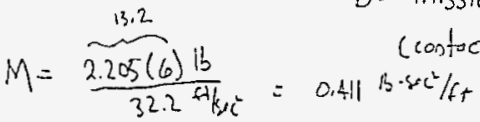

$$
\begin{aligned}
& v=\sqrt{2 g d}=\sqrt{2 \times 32.2 \cdot 3.281}=14.5 \mathrm{ft} / \mathrm{sec}
\end{aligned}
$$

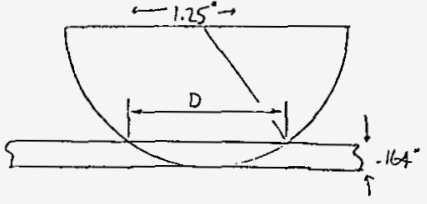

$$
\begin{aligned}
& \left(\frac{1}{2} D\right)^{2}=2\left(\frac{1.25}{2}\right)(.164)-.164^{2} \quad D=.844^{\prime \prime} \\
& T=\frac{\left(.411 \times 14.5^{2} / 2\right)^{2 / 3}}{672 \times .844}=.0218^{\prime \prime} \quad 1.25 T=.027^{4}
\end{aligned}
$$

0D.6400.060.1 $(12 / 87\rangle$

B5-20 BEST AVALABLE COPY 
WHC-SD-TP-SEP-048

Rev. 0

DESIGN CALCULATION

(1) Drawing

(4) Building

(7) Subject

(8) Originator

(9) Checker
(2) Dos. No.

(5) Rev.

222-5 CARCO TAMK

uss

(10) There is a large margin $\left(.027<.164^{n}\right)$ but the contact width is arbitrary. Use (Bork, 6.4) Table 30, case 8

circumferential stress $\sigma_{2}=\frac{.4 P}{t^{2}}$

$$
\begin{aligned}
& \quad y=\frac{P}{E t}\left[.48\left(\frac{L}{R}\right)^{2}(R / t)^{1.22}\right] \\
& \frac{L}{R}=\frac{449}{57.5 / 2}=15.5 \\
& \frac{R}{t}=\frac{57.5 / 2}{.164}=175 \quad E=28 E 6 \text { PSi } \\
& \therefore \quad y=\frac{P}{.164(2266)}\left[.48(155)^{\frac{y}{2}}(175)^{1.22}\right]=224 E-6 P
\end{aligned}
$$

For energy batons: $\frac{1}{2} P_{y}=w h=13.2^{\circ} \cdot 39.4^{\prime}: 500 \mathrm{n}^{*}$

$$
\begin{gathered}
\because 112 E-6 P^{2}=520, \quad P=2150^{\circ} \\
\sigma_{2}=\frac{4(2150)}{.164^{2}}=32,000>30,000 \text { (static yield) } \\
y=2150 \cdot 224 E-6=0.48^{\prime \prime}
\end{gathered}
$$

$\sigma_{2}>$ static yield but deformation is limited.

BD. $6400.060 .1(12 / 87)$

B5-21

BEST AVAILABLE COPY 
WHC-SD-TP-SEP-048 Rev. 0

This page intentionally left blank. 
WHC-SD-TP-SEP-048 ReV. 0

\subsection{THERHAL EVALUATION}

\subsection{INTRODUCTION}

The purpose of this evaluation is to demonstrate that the MC-312 Cargo Tanks maintain integrity during their lifetime for internal heat generation and Hanford environmental conditions. Evaluation of heat transfer data will include information or assumptions, as required, to determine if the package is capable of passively transferring the heat load to the environment.

\subsection{THERMAL SOURCE SPECIFICATION}

As part of the hydrogen gas generation evaluation, the heat output from the cargo tank radioactive source term listed in Table B2-1 was calculated to be $0.052 \mathrm{~W}$. This information is provided in Part B, Section 7.3.

\subsection{SUMMARY OF THERMAL PROPERTIES OF MATERIALS}

The absorption factor for T316, T316L, and 304 stainless steel that is not coated or painted is 0.18 for the empty cargo tank and 0.30 for the full cargo tank.

\subsection{THERMAL EVALUATION FOR NORMAL TRANSFER CONDITIONS}

The cargo tanks were evaluated for surface temperature under full and empty conditions. The calculations are shown in Section 6.7. The maximum surface temperature was found for the cargo tank nearly empty. Using Site-specific peak solar irradiation from Environmental Conditions for On-Site Hazardous Materials Packages (WHC 1992) and thermal absorptivity appropriate for stainless steel, the maximum surface temperature is $59^{\circ} \mathrm{C}\left(138^{\circ} \mathrm{F}\right)$. This produces a tank pressure increase of less than $41 \mathrm{kPa}$ (6 psi).

Internal heating was neglected. As noted in Part B, Section 6.2, internal heating produces $0.052 \mathrm{~W}$, while solar heating is $388 \mathrm{~W} / \mathrm{m}^{2}$ or $1,100 \mathrm{~W}$ on the cargo tank's projected area using an absorptivity of 0.18 .

Assuming the cargo tank to be full and assuming the emissivity and absorptivity to be 0.3 , the maximum temperature gain is $1{ }^{\circ} \mathrm{C}\left(2{ }^{\circ} \mathrm{F}\right)$ in 12 hours when subjected to the solar irradiation of $400 \mathrm{~g}-\mathrm{cal} / \mathrm{cm}^{2}$. The highest absorptivity from a standard text was used for this evaluation.

\subsection{THERMAL EVALUATION AND CONCLUSIONS}

The heat generation from the concentration of radionuclides in the liquids in the cargo tanks is very low and will not affect the cargo tank structural integrity. The cargo tank surface temperatures will not exceed safety limits due to the Hanford environmental conditions. The maximum heat loading produced an increase in internal pressure of less than $41 \mathrm{kPa}$ ( $6 \mathrm{psi}$ ), well below the cargo tank design pressure of $276 \mathrm{kPa}$ (40 psi). 
WHC-SD-TP-SEP-048; Rev. 0

\subsection{REFERENCE}

WHC, 1992, Environmental Conditions for On-Site Hazardous Material Packages, WHC-SD-TP-RPT-004, Rev. 0, Westinghouse Hanford Company, Richland, Washington.

\subsection{APPENDIX: THERMAL EVALUATION}




\section{ENGINEERING SAFETY EVALUATION}

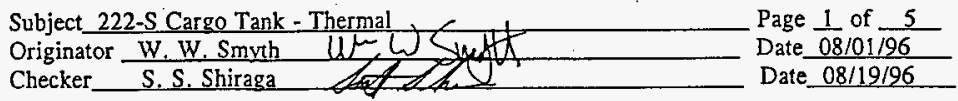

\section{Objective:}

For two (2) MC-312 tanks. Find the maximum tank temperature.

\section{References:}

10 CFR 71, "Packaging and Transportation of Radioactive Material," Code of Federal Regulations, as amended.

Irwin, J. J., 1995, Thermal Analysis Merhods for Safety Analysis Reports for Packaging, WHC-SD-TP-RPT-005, Rev. 1, Westinghouse Hanford Company, Richland, Washington.

Pauling, L., 1970, General Chemistry, WH Freeman.

White, 1991, Heat and Mass Transfer, Addison-Wesley.

III. Results and Conclusions:

A full tark heats less than $2^{\circ} \mathrm{F}$ due to solar irradiation specified in 10 CFR 71 .

An empty tank under the peak hourly Hanford solar irradiation will have a surface temperature of $138^{\circ} \mathrm{F}$ and a pressure of less than 6 psig. 


\section{ENGINEERING SAFETY EVALUATION}

Subject 222-S Cargo Tank - Thermal

Originator W.W. Smvth

Checker S. S. Shiraga

Page 2 of 5

Date $08 / 01 / 96$

Date $08 / 19 / 96$

\section{Evaluation:}

\section{Thermal - Full Tank}

Acceptance: Maximum tank temperature $\leq 180^{\circ} \mathrm{F}$ (10 CFR 71.41).

Assume no internal heating. Use 10 CFR 71.41.

Insolation of $400 \mathrm{~g}-\mathrm{cal} / \mathrm{cm}^{2}$ at $115^{\circ}$ ambient air temperature for 12 hours.

$$
400 \frac{\mathrm{g}-\mathrm{cal}}{12 \mathrm{~h} / \mathrm{cm}^{2}}=\frac{400 \cdot 4.1868 \mathrm{~J}}{12 \cdot 3,600(0.01)^{2}}=338 \frac{\mathrm{W}}{\mathrm{m}^{2}}
$$

Use Heat and Mass Transfer (White 1991) for thermal data. $\epsilon=$ emissivity (= absorptivity) is between 0.17 and 0.30 for polished stainless steel at temperatures between $300 \mathrm{~K}$ and $1000 \mathrm{~K}$. Use 0.30 .

Consider a $1 \mathrm{~m}$ length of tank.

Heat capacity: $\Sigma C_{p} \cdot$ mass

$$
\begin{array}{lll}
\text { SS: } & \mathrm{C}_{\mathrm{p}}=477 \mathrm{~J} / \mathrm{kg} \cdot \mathrm{K} & \mathrm{p}=7,900 \mathrm{~kg} / \mathrm{m}^{3} \\
\text { water: } & \mathrm{C}_{\mathrm{p}}=4,176 \mathrm{~J} / \mathrm{kg} \cdot \mathrm{K} & \mathrm{p}=1,000 \mathrm{~kg} / \mathrm{m}^{3}
\end{array}
$$

Total heat capacity:

$$
\pi \frac{(1.46)^{2}}{4} \cdot 1 \cdot 1000 \frac{\mathrm{kg}}{\mathrm{m}^{3}} \cdot 4,176+\pi(1.46)(0.00417) \cdot 7,900 \frac{\mathrm{kg}}{\mathrm{m}^{3}} \cdot 477=7.063 \mathrm{E}+06 \frac{\mathrm{J}}{\mathrm{K}}
$$

12 hour $\Delta \mathrm{T}: \quad \frac{12 \cdot 3,600 \cdot 388 \cdot 0.3 \cdot 1.46 \mathrm{~m}}{7.063 \mathrm{E}+06}=1.04 \mathrm{~K}=2{ }^{\circ} \mathrm{F}$

Tank temperature $\approx 2{ }^{\circ} \mathrm{F}$ over tank contents in one day, ignoring heat loss by tank. 
ENGINEERING SAFETY EVALUATION

$\begin{array}{ll}\text { Subject 222-S Cargo Tank - Thermal } & \text { Page } 3 \text { of } \frac{5}{5} \\ \text { Originator } \frac{\text { W. W. Smyth }}{\text { S. S. Shiraga }} & \text { Date } 08 / 01 / 96 \\ \text { Checker Date } 08 / 19 / 96\end{array}$

\section{Empty Tank:}

Assume the air in the tank is the same as the shell and the shell is uniform temperature. The shell temperature will be found by iteratively solving a heat flow balanced equation.

$$
\begin{aligned}
& Q_{\text {solar }}-Q_{\text {cosvcet. }}-Q_{\text {rad }}=0 \\
& \mathrm{Q}_{\text {solar }}=\epsilon \cdot \mathrm{Q}_{\mathrm{I}} \cdot \mathrm{P}_{\mathrm{i}} \\
& \mathrm{P}_{\mathrm{f}}=1.46 \mathrm{~m}^{2} \quad \epsilon=\text { emissivity (= absorptivity) } \\
& \mathrm{Q}_{1}=\text { insolation }
\end{aligned}
$$

The 316 stainless steel is highly polished surface. The Site standard for thermal analysis of packagings (Irwin 1995) suggests $\epsilon=0.15$ for polished $18-8$ stainless steel at $100^{\circ} \mathrm{F}$. A text (White 1991) gives a range: 0.17 at $300 \mathrm{~K}\left(81^{\circ} \mathrm{F}\right)$ to 0.30 at $1000 \mathrm{~K}$. Interpolation for a value at $350 \mathrm{~K}\left(170^{\circ} \mathrm{F}\right)$ gives $\underline{\underline{0.18}}$.

$\mathrm{Q}_{\mathrm{I}}=388 \mathrm{~W} / \mathrm{m}^{2}$ for a 12 hour average, on a horizontal surface. Thermal Analysis Methods for Safety Analysis Reports for Packaging (Inwin 1995) distributes onsite and 10 CFR data over time and recommends $72.1 \mathrm{~g}-\mathrm{cal}_{1} \mathrm{~cm}^{2}$ for the peak 1 hour insolation.

Convert to $\mathrm{W} / \mathrm{m}^{2}: \quad \frac{72.1 \cdot 4.1868 \mathrm{~J}}{3,600 \mathrm{sec}(0.01)^{2} \mathrm{~m}^{2}}=839 \frac{\mathrm{W}}{\mathrm{m}^{2}}$

This exceeds the 10 CFR requirements and is more appropriate for a stainless steel plate.

$$
\mathrm{Q}_{\mathrm{xolax}}=0.18(839) 1.46=221 \mathrm{~W}
$$

$$
Q_{\mathrm{rad}}=\epsilon \sigma A_{\mathrm{rad}}\left(\mathrm{T}_{\mathrm{s}}^{4}-\mathrm{T}_{0}^{4}\right)
$$

$\sigma=$ Stefan-Boltzman constant $=5.67 \mathrm{E}-08 \mathrm{~W} / \mathrm{m}^{2} \mathrm{~K}$

$\epsilon=0.18$

$A_{\text {rad }}=$ surface area of $1 \mathrm{~m}$ length of tank $=\pi \mathrm{d}=4.59 \mathrm{~m}^{2}[$ form factor $=1]$

$\mathrm{T}_{\mathrm{s}}=$ surface temperature, $\mathrm{K}$

$\mathrm{T}_{0}=$ surrounding temperature

(Irwin 1995), $\mathrm{T}_{0}=115^{\circ} \mathrm{F}=319 \mathrm{~K}$

$$
Q_{\text {red }}=46.85 \mathrm{E}-09\left(T_{s}^{4}-T_{0}^{4}\right)
$$


ENGINEERING SAFETY EVALUATION

Subject 222-S Cargo Tank - Thermal

Originator W.W. Smvth Page 4 of 5

Checker

Thermal Analysis Methods for Safety Analysis Reports for Packaging (Irwin 1995) recommends:

$$
\mathrm{h}_{\mathrm{c}}=\frac{0.27\left(\mathrm{~T}_{\mathrm{s}}-\mathrm{T}_{0}\right)^{0.25}}{\mathrm{D}^{0.25}} \frac{\mathrm{BTU}}{\mathrm{h} \mathrm{ft}^{2} \mathrm{R}}
$$

for $D$ in $\mathrm{ft}, \mathrm{T}$ in $\mathrm{R}$

for a $20^{\circ} \mathrm{F}$ difference in temperature and $\mathrm{d}=57.5 / 12=4.79$

$$
\begin{aligned}
h_{c}= & 0.27\left(\frac{20}{4.79}\right)^{0.25}=0.368 \frac{B T U}{\mathrm{~h} \mathrm{ft}^{2} \mathrm{R}} \\
\mathrm{h}_{c}= & 0.368 \cdot 5.678=2.19 \frac{\mathrm{W}}{\mathrm{m}^{2} \mathrm{~K}} \\
\mathrm{Q}_{\text {coov }}= & 2.19(4.59)\left(\mathrm{T}_{\mathrm{s}}-\mathrm{T}_{0}\right)=10.1\left(\mathrm{~T}_{\mathrm{s}}-\mathrm{T}_{0}\right) \mathrm{W} \\
& \text { as long as } \mathrm{T}_{s}-\mathrm{T}_{c}=20^{\circ} \mathrm{F}
\end{aligned}
$$

Heat balance:

$$
221-10.1\left(\mathrm{~T}_{s}-\mathrm{T}_{0}\right)-46.9 \mathrm{E}-09\left(\mathrm{~T}_{\mathrm{s}}{ }^{4}-\mathrm{T}_{0}{ }^{4}\right)=\mathrm{F}\left(\mathrm{T}_{\mathrm{s}}\right)=0
$$

Solve by iteration (Newton's method): $\quad x_{n+1}=x_{a}-\frac{F\left(x_{n}\right)}{F^{\prime}\left(x_{n}\right)}$

start with $x_{0}=320$

\begin{tabular}{|c|c|c|c|c|c|c|}
\hline $\mathrm{T}_{s}\left({ }^{\circ} \mathrm{K}\right)$ & $\mathrm{T}\left({ }^{\circ} \mathrm{F}\right)$ & $\mathrm{Q}_{\operatorname{cosv}}$ & $\mathrm{Q}_{\mathrm{sd}}$ & $\mathrm{F}\left(\mathrm{T}_{\mathrm{s}}\right)$ & $\mathrm{F}^{\prime}\left(\mathrm{T}_{\mathrm{s}}\right)$ & $-\mathrm{F} / \mathrm{F}$ \\
\hline \hline 320 & 116.0 & 7.4 & 4.5 & 208.5 & - & \\
\hline 321.0 & 117.8 & 17.5 & 10.7 & 192.3 & -16.2 & 11.87 \\
\hline 332.9 & 139.2 & 136.7 & 88.3 & -4.5 & -16.6 & -0.27 \\
\hline 332.6 & 138.7 & 133.9 & 86.5 & 0.1 & -16.9 & 0.01 \\
\hline
\end{tabular}

Surface temperature: $\quad T_{\mathrm{t}}=139^{\circ}$ for $115^{\circ}$ ambient and $\epsilon=0.18$

$\Delta T=23^{\circ}$ which is close to 20 
WHC-SD-TP-SEP-048 ReV. 0

ENGINEERING SAFETY EVALUATION

Subject 222-S Cargo Tank - Thermal

Originator W. W. Smyth Page 5 of 5

Checker S. S. Shiraga

Date $0 8 / 0 1 \longdiv { 1 9 6 }$

Date $08 / 19 / 96$

Find the tank pressure due to temperature rise and vapor pressure. Assume the tank was filled at $40^{\circ} \mathrm{F}$, then emptied after stabilizing at $40^{\circ} \mathrm{F}$, then heats to a uniform $139^{\circ} \mathrm{F}$.

Water vapor pressure at $139^{\circ} \mathrm{F}\left(59^{\circ} \mathrm{C}\right)<0.1965$ atm (Pauling 1970):

$$
0.20 \cdot 14.7 \mathrm{psi}=2.9 \mathrm{psi}
$$

$\Delta \mathrm{P}$ due to temperature:

$$
\frac{P_{1}}{T_{1}}=\frac{P_{2}}{T_{2}} \quad \frac{14.7}{460+40}=\frac{P_{2}}{460+139} \quad P_{2}=17.6 \mathrm{psi}
$$

$\Delta \mathrm{P}=\mathrm{P}_{2}-\mathrm{P}_{1}=2.9 \mathrm{psi}$

Total pressure $=2.9+2.9=5.8 . \mathrm{psi}<<40$ (design) 
WHC-SD-TP-SEP-048 Rev. 0

This page intentionally left blank.

B6-8 


\subsection{PRESSURE AND GAS GENERATION}

\subsection{GAS GENERATION}

The purpose of this evaluation is to predict hydrogen gas generation and pressure buildup in the MC-312 Cargo Tanks.

Hydrogen generation and pressure buildup can occur within a package as a result of the radiolytic decomposition of the package contents.

The cargo tanks contain dissolved cations and anions in a water solution as described in Part $A$, Section 3.0. Based on the source term provided for the cargo tanks, the radiolytic gas generation was predicted. The analysis is presented in Part B, Section 7.3.

\subsection{PACKAGE PRESSURE}

The analysis showed that the hydrogen generation rate is extremely low and is not a concern for transportation. The worst-case scenario for hydrogen concentration is one in which the cargo tank is completely sealed. Based on these results, the $2.5 \%$ limit applied to transportation would take approximately 18 years to reach. The results also showed for the period of time to reach the $2.5 \%$ hydrogen limit, the pressure buildup inside the cargo tank would be $2.57 \mathrm{kPa}(0.37 \mathrm{psi})$. Based on the time required for transportation and the fact the cargo tanks have a design pressure of $276 \mathrm{kPa}$ (40 psi), pressure buildup is not a concern.

In summary, the analysis showed that, even with several very conservative assumptions, hydrogen generation is not a problem for transporting the cargo tanks. 


\subsection{APPENDIX: HYDROGEN GENERATION EVALUATION}

ENGINEERING SAFETY EVALUATION
Subject Hvdrogen Gas Generation in a 222-S Cargo
Originator J. R. Green
Checker J. E. Mercado

\section{Objectives:}

4000 gallons $\left(1.514 \times 10^{7} \mathrm{cc}\right)$ of liquid waste will be shipped in the 222-S Cargo Tank which is authorized to transport bulk LSA liquids onsite. Calculations of the hydrogen generation rate, the time to $2.5 \% \mathrm{H}_{2}$ gas concentration by volume, and the decay heat from the inventory are required to ensure transportation safety.

II. Reference:

Green, J. R., K. Hillesland, V. E. Roetman, and J. G. Field, 1995, Radcalc for Windows, Version 1.0, Westinghouse Hanford Company, Richland, Washington.

III. Results and Conclusions:

A $5000 \mathrm{gal}\left(1.893 \times 10^{7} \mathrm{cc}\right)$ gallon tank truck containing 4000 gallons of liquid waste in aqueous form will reach $2.5 \% \mathrm{H}_{2}$ gas concentration by volume in approximately 18 years. The hydrogen gas generation rate is $0.60 \mathrm{cc} / \mathrm{h}$. The decay heat generates $0.0516 \mathrm{~W}$. The tank primarily contains water.

It does however contain less than 1 wejght percent organic carbons which were modeled as a straightchain hydrocarbon. Accordingly, the G-values for the calculation were conservatively based on 90 weight percent water and 10 weight percent straight-chain hydrocarbon (hexane). The values used will result in conservarive results.

IV. Engineering Evaluation:

The computer code Radcalc for Windows (Green et al. 1995) was used to calculate the production of hydrogen gas in a 4600 gallon tank. The information supplied for the analysis follows:

\begin{tabular}{|l|l|l|}
\hline Waste Volume & 4000 gallons \\
\hline Total Tank Volume & 5000 gallons \\
\hline Waste Density & $1.2 \mathrm{~g} / \mathrm{cc}$ \\
\hline Waste Matrix & 99 w/o water & I w/o organic carbon \\
\hline Radioactive Components & See Table 1. \\
\hline
\end{tabular}


ENGINEERING SAFETY EVALUATION

Subject Hydrogen Gas Generation in a 222-S Cargo
Originator J.R. Green
Checker J.E. Mercado

The following input parameters were used in the Radcalc for Windows computer code:

\begin{tabular}{|l|l|l|l|}
\hline Waste Volume & \multicolumn{1}{|l|}{$15.142 \mathrm{~m}^{3}$} \\
\hline Void Volume & $3.7854 \mathrm{~m}^{3}$ & \\
\hline Waste Weight & $1.817 \times 10^{7} \mathrm{~g}$ & \\
\hline Gamma Absorption Fraction Basis & LR-56 & & \\
\hline G-value & Gamma & Beta & Alpha \\
Water (90 w/o) & .45 & 0.53 & 1.6 \\
Organic carbon (10 w/0) & 5.3 & 5.3 & 21.2 \\
\hline Radioactive Components & See Table 1 & \\
\hline
\end{tabular}

The fraction of gammas absorbed in the waste tark is a function of energy and geometry. The most conservative values for the gamma absorption fractions contained in Radcalc for Windows are those which are calculated for the LR-56. Therefore, the LR-56 container was used to model the tank because the 222-S cargo tank is not modeled within the code.

The $\mathrm{H}_{2} \mathrm{G}$-value is a measure of the number of molecules of $\mathrm{H}_{2}$ gas formed per $100 \mathrm{eV}$ of energy absorbed in the waste matrix. G-values are supplied in Radcalc for Windows for a variety of material types. The liquid waste to be shipped in the tank trucks is primarily water with less than 1 weight percent composed of an organic carbon modeled as a straight-chain hydrocarbon. Water was conservatively assumed to compose 90 weight percent of the solution and a straight-chain hydrocarbon 10 weight percent. The $G$-values are high and will resuit in conservative values for the material being shipped.

The above parameters were input into Radcalc for Windows which calculated the number of days to $2.5 \%$ hydrogen gas concentration by volume to be 6659 days (18.23 years). The hydrogen generation rate is $0.60 \mathrm{cc} / \mathrm{h}$. The decay heat from the inventory is $0.0516 \mathrm{~W}$. A copy of the Radcalc input/output file is attached. The uncertainties in this analysis are represented primarily by the uncertainty of the $G$-value of the waste matrix. The value used is very conservative and may result in an over estimation of the quantity of hydrogen gas produced. 
WHC-SD-TP-SEP-048 Rev. 0

ENGINEERING SAFETY EVALUATION

Subject Hudroger Gas Generation in a 222-S Cargo Page 3 of 3 Originator $\mathrm{J}$. R. Green Checker J. E. Mercado

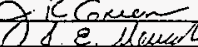
Date $06 / 28 / 96$

Date $06 / 28 / 96$

Table 1. 222-S Cargo Source Term

\begin{tabular}{cl} 
Radionuclide & \multicolumn{1}{c}{ Curies } \\
H-3 & $8.40 \mathrm{e}-001$ \\
$\mathrm{C}-14$. & $6.50 \mathrm{e}-003$ \\
Co-60 & $4.35 \mathrm{e}-001$ \\
$\mathrm{Sr}-90$ & $2.63 \mathrm{e}+000$ \\
Y-90 & $2.63 \mathrm{e}+000$ \\
Tc-99 & $5.50 \mathrm{e}-002$ \\
$\mathrm{I}-129$ & $4.80 \mathrm{e}-002$ \\
Cs-137 & $2.61 \mathrm{e}+000$ \\
Ba-137m & $2.47 \mathrm{e}+000$ \\
Pm-147 & $7.50 \mathrm{e}+000$ \\
Eu-154 & $5.54 \mathrm{e}-003$ \\
Th-23! & $8.50 \mathrm{e}-005$ \\
$\mathrm{U}-234$ & $1.45 \mathrm{e}-002$ \\
$\mathrm{U}-235$ & $8.50 \mathrm{e}-005$ \\
$\mathrm{U}-238$ & $1.40 \mathrm{e}-003$ \\
Pu-238 & $2.15 \mathrm{e}-002$ \\
Pu-239 & $1.85 \mathrm{e}-001$ \\
Am-241 & $1.45 \mathrm{e}-001$
\end{tabular}


WHC-SD-TP-SEP-048 ReV. 0

Radeale for vindows 1.0

Date: 05-27-96 09:51

File: 222SREVI, RAD

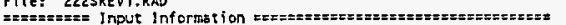

Performed By: 9 Cacem 6/27/96

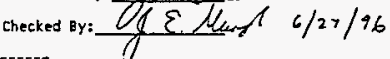

source from inpur

Radionuclide: curies:

$\mathrm{H}=3$ 8.60e-001

$c+14 \quad 6.50 \mathrm{e}-003$

co-60 4.35t-001

$\$ r .90 \quad 2.63 t+000$

$Y-90 \quad 2.63 \mathrm{e}+000$

$1 c+99 \quad 5.50 \mathrm{e}-002$

$1.129 \quad 4.80 \mathrm{e}-002$

Cs $-137 \quad 2.61 \mathrm{e}+000$

$\begin{array}{ll}\mathrm{Ea}-137 \mathrm{~m} & 2.67 \mathrm{e}+000 \\ \mathrm{Pm}-147 & 7.50 \mathrm{e}+000\end{array}$

Eu- $154 \quad 5.52 \mathrm{e}-003$

Th-23i 8.50e-005

$u-234 \quad 1.45 \mathrm{e}-002$

U. $235 \quad 8.50 e^{-005}$

$u-238 \quad 1.20 e-003$

Pu-238 2.15e-002

Pu-239 1.85e-001

An $-241 \quad 1.65 e-009$

Waste form: Normal

Physical form: liquid

Container Type: LR-S6

Package Void Volune:

Haste velume:

$1.65 e-009$

haste Hass:

Waste True Density:

$3.79 \mathrm{e}+006 \mathrm{cc}$

$1,59 \mathrm{e}+007 \mathrm{cc}$

$1.82 \mathrm{e}+007 \mathrm{~g}$

$1.20 \mathrm{~g} / \mathrm{cc}$

Date to begin source decey: 11:00 May. 23, 1996

Date container sealed: 11:00 May. 23, 1996

Days to decay source befote sest time: 0.00 days

Calculate number of days seded untit $2.50 \%$ hydrogen is reached.

G Value Masterial selection:

\begin{tabular}{|c|c|c|c|c|c|}
\hline $\begin{array}{l}\text { Cont ribution } \\
90.00 \% \\
10.00 \%\end{array}$ & $\begin{array}{r}\text { Weight } \\
0.9 \\
0.1\end{array}$ & $\begin{array}{c}\text { G-A1phs } \\
1.6 \\
21.2\end{array}$ & $\begin{array}{c}0.5 \text { eta } \\
0.53 \\
5.3\end{array}$ & $\begin{array}{c}\text { G. Gampia } \\
0.45 \\
5.3\end{array}$ & $\begin{array}{l}\text { Name } \\
\text { Hater (liquid) } \\
\text { Hexane }\end{array}$ \\
\hline
\end{tabular}

(" indicates the value was calculated from a given value)

$G$ values calculated from list overaging:

$\begin{array}{lll}\text { G Alpha G Gets } & \text { G Garms } \\ 3.56 & 1.007 & 0.535\end{array}$

Compents:

G-Values were chosen on she bssis of $90 \mathrm{H} / 0$ woter and 10

W/o straight chain hydroearben which will bound the

organic in the liquid

Exemzeze Calculated Results

The sealed container will generste $2.47 \mathrm{x}$ hydrogen in 6658.79 days

This corresponds to dete:

H2 Vol une:

6:00 Aug. 16, 2014

32 Generation kate. $\quad 9.59 \mathrm{e}+004 \mathrm{ce}$

Hebt Generated:

$\begin{array}{ll}\text { Partial Pressure (H2): } & 2,57 \mathrm{kPa} \\ \text { Total Pressure (K2 and Air): } & 104 . \mathrm{kPa}\end{array}$

Bulk Density:

$1.20 \mathrm{~g} / \mathrm{cc}$

Source decayed to start of seal time:

Radionuclide: curfes:

$\mathrm{H} \cdot 3 \mathrm{~S} \quad \mathrm{8} .4 \mathrm{Oe}-001$

$\mathrm{c}-16 \quad 6.50 \mathrm{e}-003$

Co. $60 \quad 4.35 \mathrm{e}-001$ 
WHC-SD-TP-SEP-048 ReV. 0

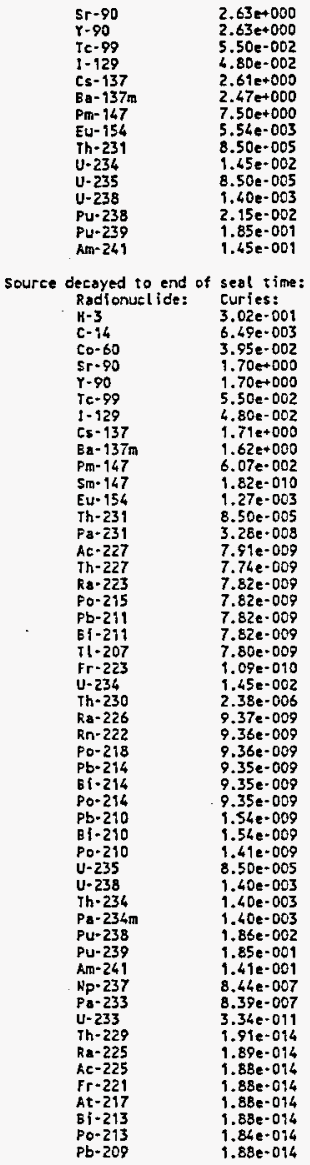


WHC-SD-TP-SEP-048 Rev. 0

\subsection{PACKAGE TIEDOWN SYSTEM EVALUATION}

\subsection{INTRODUCTION}

The MC-312 Cargo Tanks are permanently secured to their transport trailer. The cargo tank is welded to the rear suspension system, which, in turn, is fastened to the trailer frame. The fifth-wheel assembly in front is fastened to the suspension system and trailer frame, using a heavy plate with an adjustable double-hubbed kingpin. The cargo tanks are ASME certified and have a COC from the vendor certifying the cargo tanks meet the DOT Motor Vehicle Cargo Tank Specifications. The cargo tank transport system has a design 1 ife of 30 years. An evaluation of a tiedown system for the MC-312 Cargo Tanks is not required. 


\section{WESTINGHOUSE HANFORD COMPANY \\ UNCLASSIFIED DOCUMENT RELEASE RECORD}

Document No.:WHC-SD-TP-SEP-048

Copy No.:

Document Title: SEP (Onsite) Transport of LSA-II Liquids in MC-312 Cargo Tanks

THIS IS A COPY CONTROLLED DOCUMENT.

CUSTODIAN IS RESPONSIBLE FOR RECORDING

ALL INFORMATION UPON RECEIVING A NEW RELEASE

\begin{tabular}{|c|c|c|c|c|c|c|c|c|}
\hline $\begin{array}{l}\text { Rel. } \\
\text { No. }\end{array}$ & $\begin{array}{c}\text { Date } \\
\text { Inserted }\end{array}$ & $\begin{array}{l}\text { Revised By } \\
\text { Initials }\end{array}$ & $\begin{array}{l}\text { Rel. } \\
\text { No. }\end{array}$ & $\begin{array}{c}\text { Date } \\
\text { Inserted }\end{array}$ & $\begin{array}{l}\text { Revised By } \\
\text { Initials }\end{array}$ & $\begin{array}{l}\text { Rel. } \\
\text { No. }\end{array}$ & $\begin{array}{c}\text { Date } \\
\text { Inserted }\end{array}$ & $\begin{array}{l}\text { Revised By } \\
\text { Initials }\end{array}$ \\
\hline & & & & & & & & \\
\hline & & & & & & & & \\
\hline & & & & & & & & \\
\hline & & & & & & & & \\
\hline & & & & & & & & \\
\hline & & & & & & & & \\
\hline & & & & & & & & \\
\hline & & & & & & & & \\
\hline & & & & & & & & \\
\hline & & & & & & & & \\
\hline & & & & & & & & \\
\hline & & & & & & & & \\
\hline & & & & & & & & \\
\hline & & & & & & & & \\
\hline & & & & & & & & \\
\hline & & & & & & & & \\
\hline & & & & & & & & \\
\hline & & & & & & & & \\
\hline & & & & & & & & \\
\hline & & & & & & & & \\
\hline & & & & & & & & \\
\hline & & & & & & & & \\
\hline & & & & & & & & \\
\hline & & & & & & & & \\
\hline & & & & & & & & \\
\hline & & & & & & & & \\
\hline & & & & & & & & \\
\hline & & & & & & & & \\
\hline & & & & & & & & \\
\hline & & & & & & & & \\
\hline & & & & & & & & \\
\hline
\end{tabular}


UDC UNCLASSIFIED COVERSHEET

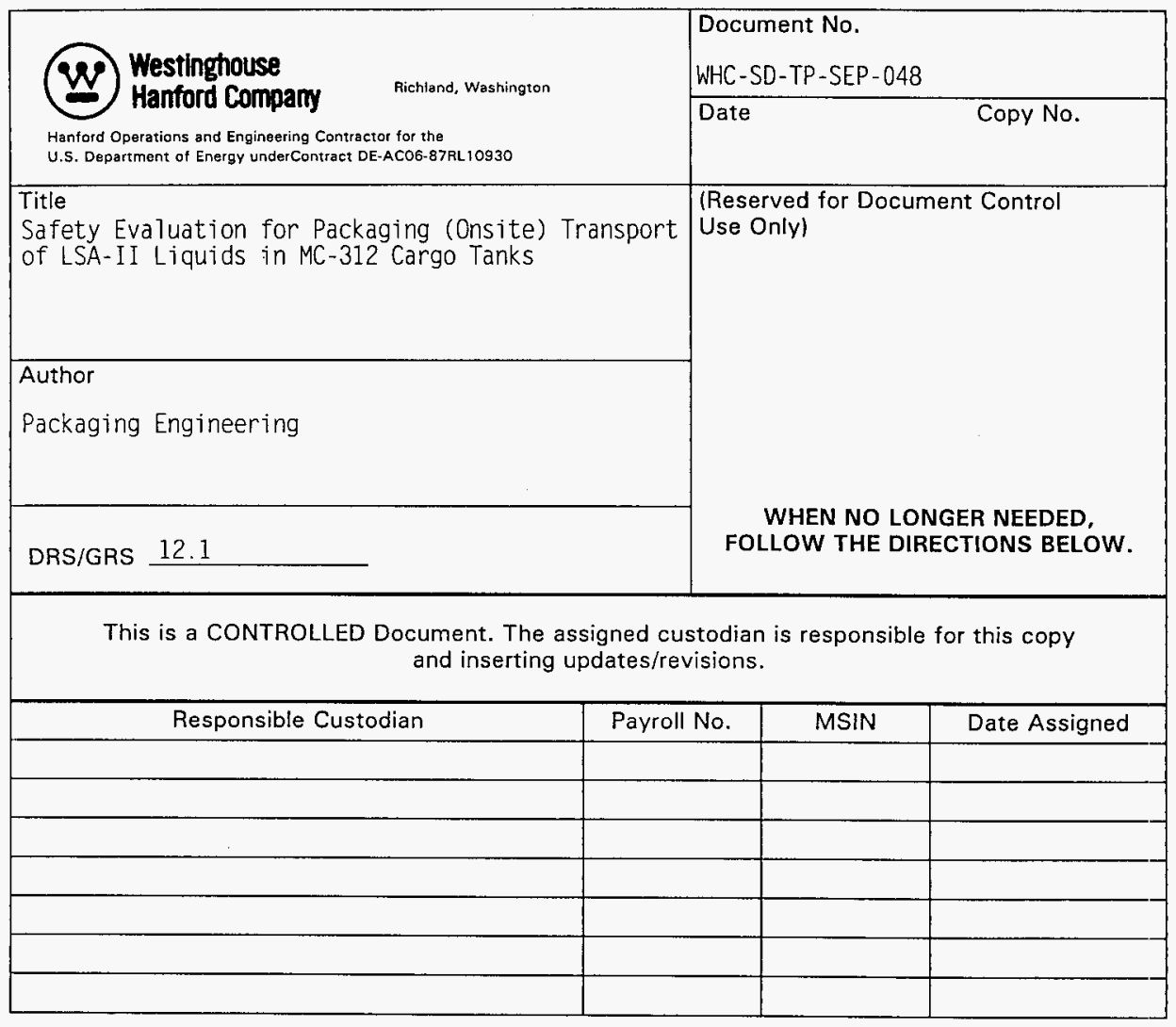

\section{TO REASSIGN OR RETURN DOCUMENT}

TO REASSIGN: Write the new custodian's name, payroll number and MSIN below the original custodian's information. Return this UDC Unclassified Coversheet to the address below.

TO RETURN: When document is no longer needed, please recycle/destroy contents and binder, sign and date this UDC Unclassified Coversheet and return it indicating

"Destroyed" to the address below.

POSTAL MAIL:

Westinghouse Hanford Co.

P.O. Box 1970/A3-95

Richland, WA 99352
PLANT MAIL:

Unclassified Document Control

A3-95

376-6831 


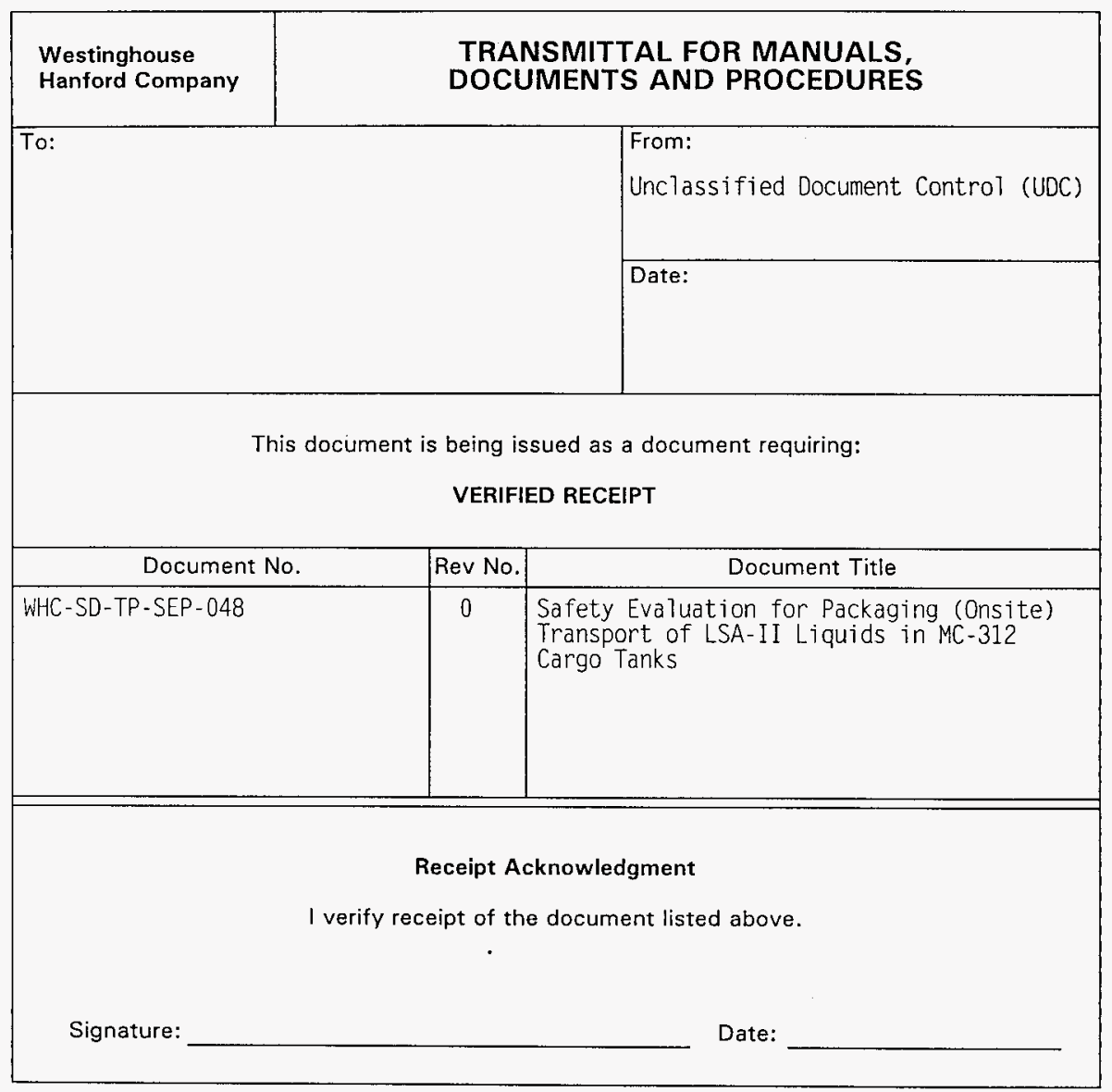

Fold To Dotted Line

PLEASE RETURN THIS SIGNED ACKNOWLEDGMENT TO:

L. M. Hay

G1-11 